\title{
GROUND WATER IN THE NORTH SIDE PUMPING DIVISION, MINIDOKA PROJECT MINIDOKA COUNTY, IDAHO
}

Prepared on behalf of the United States Bureau of Reclamation, and in cooperation with the Idaho State Department of Reclamation 
UNITED STATES DEPARTMENT OF THE INTERIOR

Douglas McKay, Secretary

GEOLOGICAL SURVEY

W. E. Wrather, Director

GEOLOGICAL SURVEY CIRCULAR 371

\section{GROUND WATER IN THE NORTH SIDE PUMPING DIVISION MINIDOKA PROJECT, MINIDOKA COUNTY, IDAHO}

By E. G. Crosthwaite and R. C. Scott

Prepared on behalf of the United States

Bureau of Reclamation, and in cooperation with the Idaho State Department of Reclamation 
Abstract.

Introduction

Purpose and scope of investigation..............

Location and size of area...........................

Well-numbering system...........................

Acknowledgments.

Physiographic history and drainage.................

Climate....

Agricultural development.

Surface water.

Ground water.

Geologic formations and their water-bearing properties...

Younger alluvial and windblown deposits

Minidoka basalt.

Older alluvium

Burley lake beds...................................

Snake River basalt.

Water resources..

Source and disposition of water.

Ground water.

Sources, occurrence, and movement....

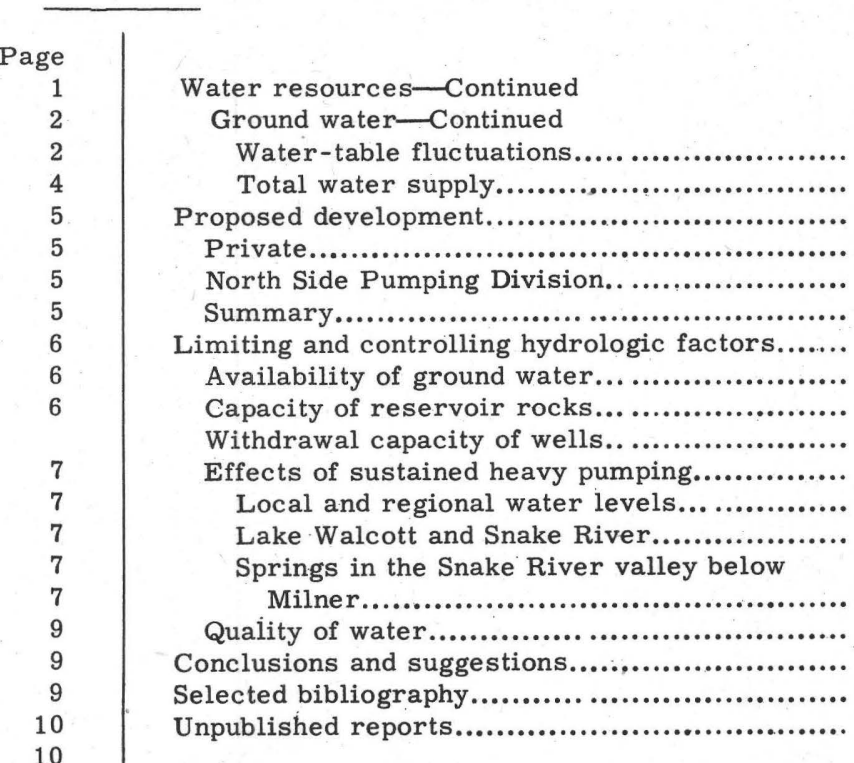

Page

10

12

12

12

13

13

13

14

14

14

15

15

15

17

17

19

20

20

\section{ILLUSTRATIONS}

Plate 1. Well locations and water-level contours in the Minidoka area, Idaho.

Figure 1. Geologic map of southern Minidoka County

2. Approximate depth to water in the Snake River basalt Minidoka area

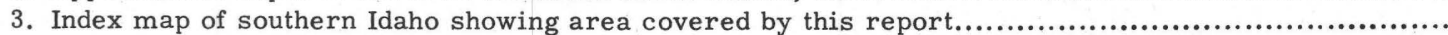

4. Water-level fluctuations in wells in Minidoka County, 1948-53.

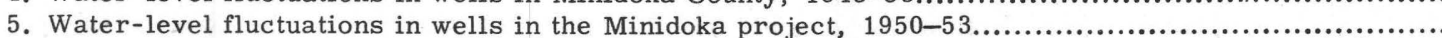

6. Graphic comparison of water-level fluctuations in well $8 \mathrm{~S}-23 \mathrm{E}-2 \mathrm{ba} 1$ with barometric pressure at Burley, March 29-April 9, 1953.

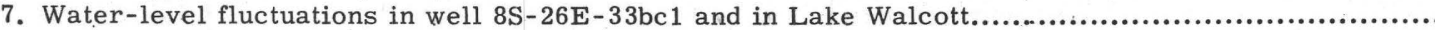

8. Relation of Lake Walcott to water levels in nearby wells (generalized).

9. Classification of irrigation water from the Minidoka area

\section{TABLES}

Table 1. Divisions of the Minidoka Project.

2. Mean annual temperature and normal annual precipitation at eight stations on the Snake River Plain.

3. Normal monthly and annual precipitation at Rupert, 1907-53.

4. Ground-water development in the Minidoka area..

5. Estimated ground-water pumpage for irrigation northeast of the Minidoka area, $1053 . \ldots .1 . . . . . . . . . .$.

6. Geologic formations and their hydrologic properties.

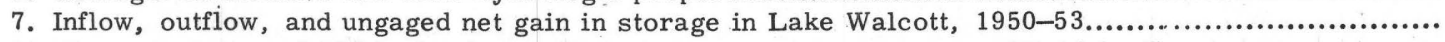

8. Characteristics of 137 irrigation wells in Unit B and adjacent area, Minidoka County....................

9. Chemical analyses of water from the Minidoka area, 1949-53. 


\title{
GROUND WATER IN THE NORTH SIDE PUMPING DIVISION MINIDOKA PROJECT, MINIDOKA COUNTY, IDAHO
}

\author{
By E. G. Crosthwaite and R. C. Scott
}

\begin{abstract}
The U. S. Bureau of Reclamation proposes to irrigate about 64,000 acres, largely in southern Minidoka County north and west of the Snake River, with ground water from 175 wells; 13,650 additional acres would receive surface water pumped to a high-line canal from Lake Milner. More than 20,000 additional acres nearby is being developed by private capital. Completion of the Federal reclamation project will more than double the irrigated acreage in the North Side Division of the Minidoka Project. The area to be irrigated with ground water is at the south-central edge of the Snake River Plain adjacent to project lands that have been irrigated for many years with Snake River water.
\end{abstract}

Substantial development of ground water for irrigation of project and private lands began in 1947. By 1953 about 79, 000 acre-feet of ground water was being pumped yearly. In four other areas to the east and northeast the estimated pumpage was about 245,000 acre-feet from the same aquifer and tributary aquifers.

The Snake River basalt is the principal waterbearing formation for all irrigation wells in the pumping project and adjacent areas. The Burley lake beds, which occur beneath the area irrigated with surface water, include thin beds of sand and gravel; these and intercalated basalt yield water to industrial, municipal, domestic, and stock wells. Clay and silt, which make up the larger part of the beds, yield little or no water to wells. Older alluvium, which mantles the Rupert terrace and overlies the Burley lake beds, yields considerable amounts of unconfined water at shallow depth. The Minidoka basalt transmits an undetermined volume of water that leaks out of Lake Walcott. Younger alluvium along the channel of the Snake River contains much ground water, but is not an important aquifer because of its small areal extent.

The principal sources of replenishment of ground water in the basalt aquifer are (1) direct infiltration of precipitation, (2) underflow from highlands and tributary valleys adjoining the Snake River Plain, (3) infiltration from surface streams and reservoirs, and (4) infiltration of unconsumed irrigation water. Westward from the project area ground water is discharged naturally from the basalt through springs in the canyon of the Snake River. The estimated yearly discharge from the springs is about 4 million acre-feet of water.
The gross ground-water requirement of reclamationproject lands will be 235,000 acre-feet yearly. The average depth to water table beneath the unit is about 200 feet and the expected average depth of wells is less than 300 feet. The anticipated average discharge from individual wells is about $5.5 \mathrm{cfs}$. The gross water requirement for 88,500 acres proposed for private development will be about 325,000 acre-feet yearly, but development of the complete acreage probably will require many years.

The foreseeable gross depletion of ground water in the project area and vicinity will be about 275,000 acre-feet yearly. Infiltration from new surface-water irrigation will offset about 30,000 acre-feet of the gross depletion, leaving a net depletion of about 245,000 acre-feet yearly. The volume of water discharged yearly from springs in the Snake River canyon probably will be reduced about 6 percent; slightly less than half the reduction will be caused by pumping on the Federal project. Foreseeable net depletion of ground water elsewhere on the plain and in tributary areas will be about 5 to 10 percent of the total historical spring flow. The proposed ground-water depletion probably would not infringe seriously on water rights at the springs or on surface-water rights downstream from the springs. Owing to the high transmissibility of the aquifer, the pumping will cause a small general lowering of water levels throughout the plain and a somewhat greater lowering in and near large pumping projects. The amount of lowering cannot be predicted at this time.

The main water table, at all places where it has been identified in the project area, is below the channel of the Snake River and the floor of Lake Walcott. The relation of Lake Walcott to the water table is complex and poorly understood, but ground-water pumping on the project is not likely to have a measurable effect on the lake. The Snake River basalt is capable of yielding water copiously to wells with but small drawdown and very little regional lowering of the water table. Decline of water levels during heavy pumping in the project will induce a large underflow of water through the basalt to the project from adjacent areas. Future pumping lifts probably will be not more than 10 feet greater than present lifts.

According to the residual sodium carbonate, percent sodium, and sodium-absorption-ratio methods of 
determining water suitability, water from the Snake River basalt is chemically suitable for irrigation. The water is moderately hard but is otherwise suitable for domestic use and for many industrial purposes.

\section{INTRODUCTION}

\section{Purpose and Scope of Investigation}

Southern Minidoka County and parts of Blaine, Jerome, and Lincoln Counties contain more than 100, 000 acres of irrigable land for which irrigation water had not been developed before 1947. Exploration and development of ground water for irrigation began on a modest scale in 1947 and were intensified thereafter. If current trends continue, most of the desirable land will be under irrigation within a few years. The North Side Pumping Division of the Minidoka Project, U. S.
Bureau of Reclamation, comprising about 78, 000 irrigable acres, is within the area of feasible development, and construction of the project has been authorized by Congress. The adopted plan of the Bureau of Reclamation provides for irrigating 64,000 acres with ground water pumped from wells, and 13,650 acres with surface water pumped from Lake Milner into a high-line canal.

This report was prepared in cooperation with the Idaho State Department of Reclamation on behalf of the Bureau of Reclamation, as an aid to project planning and construction for irrigating the North Side Pumping Division with ground water. A preliminary report (Nace, 1948) on ground water in the project and vicinity was prepared in 1948 . The present report contains a reappraisal of the ground-water aspects of the project, based on additional data collected intermittently during several subsequent years and an intensive study

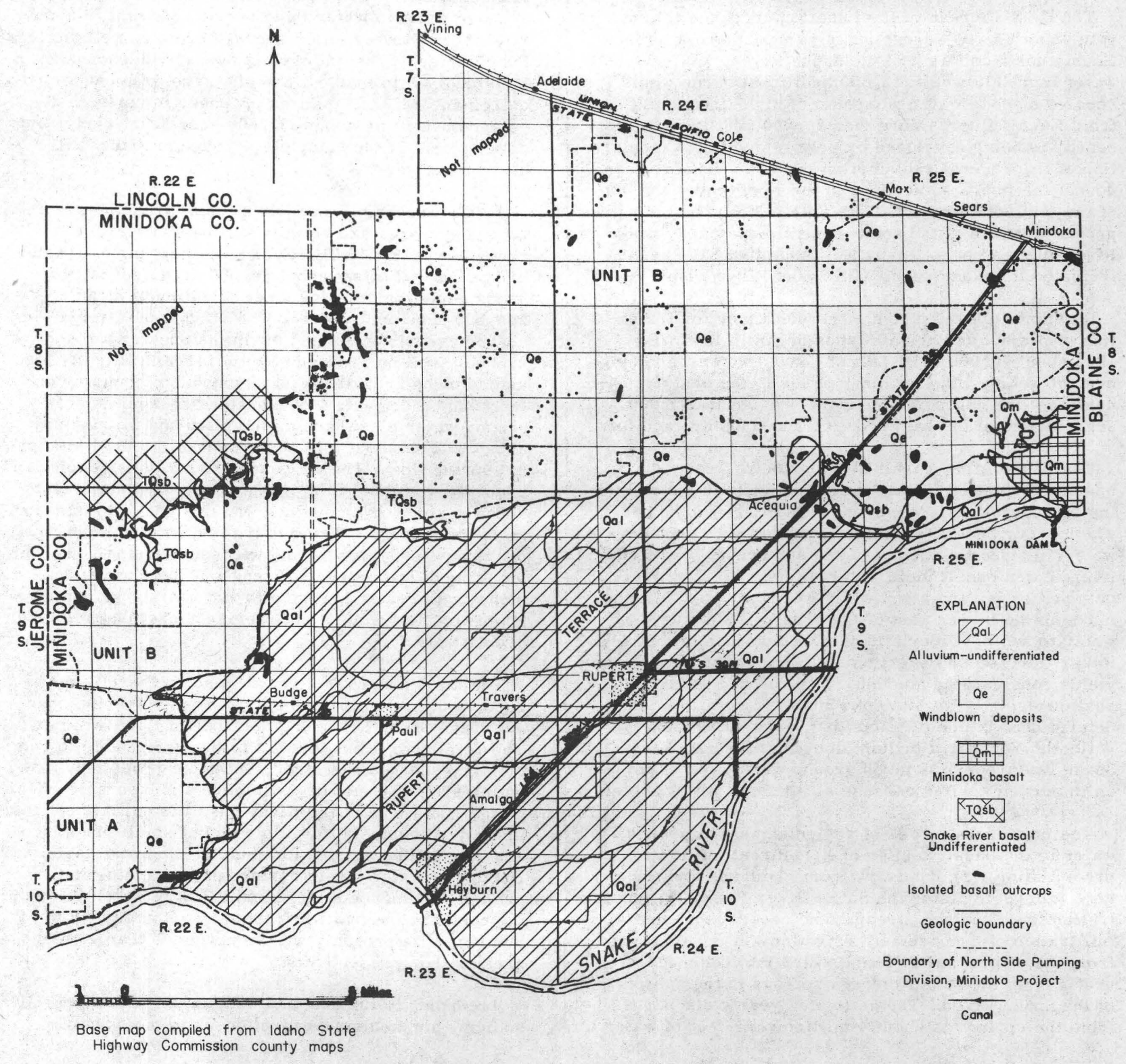

Figure 1.-Geologic map of southern Minidoka County, Idaho. 
in 1954. The present report does not entirely supersede the older one, which contains additional information about geology and water-bearing properties of rocks.

The general surface geology of the Snake River Plain, which includes the area now occupied by the North Side Pumping Division, is described by Russell (1902) and Stearns and others (1938). General geologic information and ground-water data are contained in two other reports (Nace, 1948; Fader and Mower, 1952). The Bureau of Reclamation has published a project-plan report (Newell, 1949).

Investigations in the Minidoka Project area by the U. S. Geological Survey were begun in October 1947 under a cooperative agreement with the Idaho State Department of Reclamation. Concurrently, informal technical collaboration was begun with the U. S. Bu- reau of Reclamation in the collection of hydrologic data. The Geological Survey, the Bureau of Reclamation, and the Idaho State Department of Reclamation have collaborated in the collection of all basic data.

Water levels in project observation wells have been measured by the Geological Survey since 1947. Automatic water-stage recorders are operated by the $\mathrm{Bu}-$ reau of Reclamation on 14 additional observation wells. All irrigation wells drilled before September 1953 have been canvassed. Spirit leveling to wells in the map area (pl. 1) was by the Bureau of Reclamation and the Geological Survey. The geologic map (fig. 1) was compiled from all available data. The watertable contour map (pl. 1) and the depth-to-water map (fig. 2) were prepared as part of the present report.

Ground-water investigations by the Geological Survey are under the general direction of A. N. Sayre,

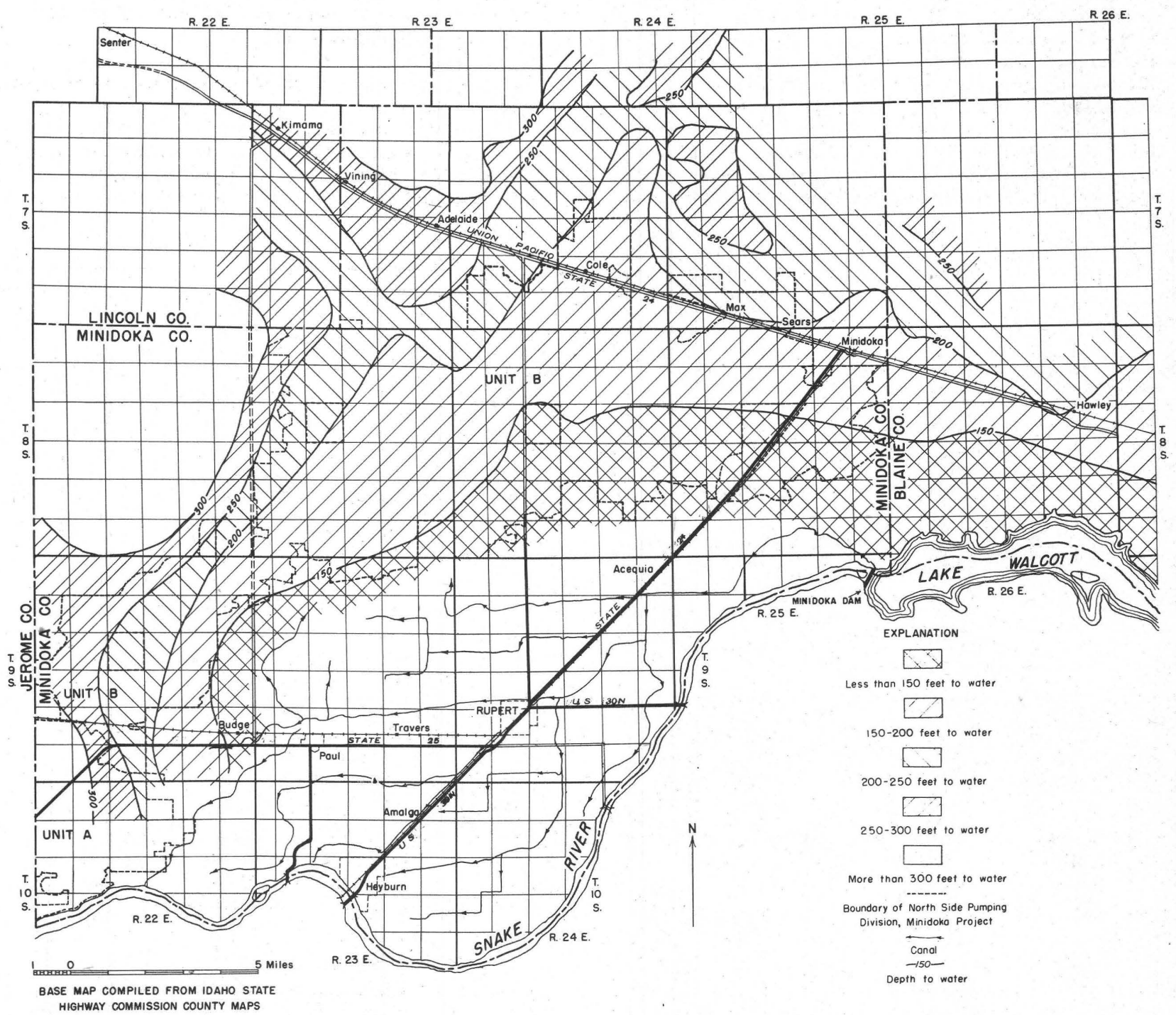

Figure 2. - Approximate depth to water in the Snake River basalt, Minidoka area, Idaho. 
chief of the Ground Water Branch. Work in Idaho is supervised by R. L. Nace, district geologist, Boise, Idaho. Work on behalf of the Bureau of Reclamation was done at the request of $\mathrm{H}$. T. Nelson, director, Region 1, U. S. Bureau of Reclamation, Boise, Idaho. The cost of the intensive study in fiscal years 1954 and 1955 was defrayed largely by Bureau of Reclamation funds. Interim work in earlier years was done in cooperation with the Idaho Department of Reclamation, Mark R. Kulp, State reclamation engineer.

Related work by the Geological Survey has been in progress west of the Minidoka Project since 1949. This work includes continuous operation of four gaging stations at the outlets of representative springs, and annual current-meter measurements at the outlets of about 20 large springs.

\section{Location and Size of Area}

The Minidoka Reclamation Project consists of several divisions (table 1). The North Side Pumping Division contains about 77,650 acres of irrigable land on the Snake River Plain in Tps. 7-10 S. , Rs. 21-25 E., Boise baseline and meridian, chiefly in southern Minidoka Gounty (fig. 3). It covers a slightly elevated belt of land 30 miles long and 2 to 7 miles wide adjacent to the north and west sides of the Gravity Division. Unit A of the Pumping Division (pl. 1) contains about 13,650 irrigable acres in the southwestern part of the project, and Unit B contains about 64,000 irri-
Table 1. -Divisions of the Minidoka Project

\begin{tabular}{|c|c|c|c|}
\hline Division & $\begin{array}{c}\text { Map } \\
\text { symbol } \\
\text { (fig. 3) }\end{array}$ & $\begin{array}{l}\text { Source } \\
\text { of } \\
\text { water }\end{array}$ & $\begin{array}{l}\text { Irrigable } \\
\text { acres } \\
\text { (rounded) }\end{array}$ \\
\hline $\begin{array}{r}\text { North Side Gravity } \\
\text { Division............. }\end{array}$ & A & Minidoka Dam.. & 72,000 \\
\hline $\begin{array}{l}\text { North Side Pump- } \\
\text { ing Division...... }\end{array}$ & \multirow[t]{2}{*}{ B } & & \\
\hline $\begin{array}{l}\text { Unit A } \\
\text { Unit B }\end{array}$ & & $\begin{array}{l}\text { Milner Dam..... } \\
\text { Ground water... }\end{array}$ & $\begin{array}{l}13,650 \\
64,000\end{array}$ \\
\hline $\begin{array}{l}\text { South Side Pump- } \\
\text { ing Division....... }\end{array}$ & \multirow[t]{2}{*}{$\mathrm{C}$} & \multirow[t]{2}{*}{ Minidoka Dam.. } & \multirow[t]{2}{*}{48,000} \\
\hline \multirow{4}{*}{$\begin{array}{l}\text { Gooding Division } \\
\text { (except Hunt } \\
\text { Unit)............... } \\
\text { Hunt Unit...... }\end{array}$} & & & \\
\hline & D & Milner Dam..... & \multirow{2}{*}{$\begin{array}{r}90,000 \\
8,000\end{array}$} \\
\hline & $\mathbf{E}$ & ..... do.............. & \\
\hline & & 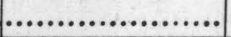 & 375,650 \\
\hline
\end{tabular}

gable acres in the northern part. The Gravity Division consists of about 72,000 acres of "oldland" $(64,000$ acres are in Minidoka County).

Under the original reclamation plan for the Minidoka Project, the North Side Pumping Division was to be irrigated with Snake River water. Because reservoirstorage space initially available did not provide for the Pumping Division land, development of that land was deferred pending availability of additional upstream

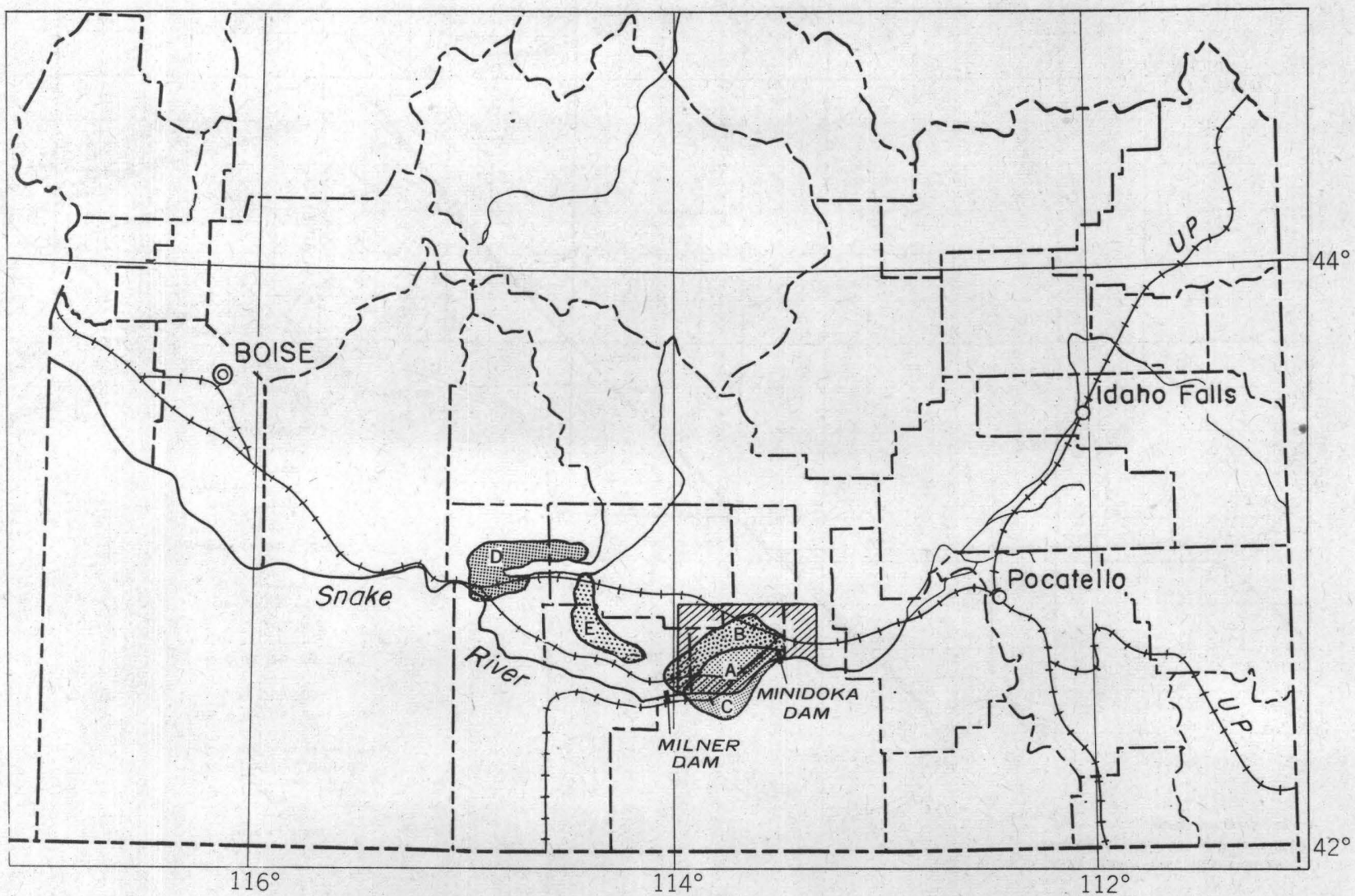

Figure 3. - Index map of southern Idaho showing area covered by this report. 
storage space. Availability of a suitable supply of ground water and development of efficient deep-well pumps, however, led to modification of the original plan. This report is concerned with the adequacy of the water supply and the feasibility of its use in Unit B. Data on adjoining areas necessarily are included to set the unit and the water-supply problem in proper geographic and hydrologic perspective.

\section{Well-Numbering System}

The well-numbering system used in Idaho by the Geological Survey indicates the locations of wells within official rectangular subdivisions of the public lands, with reference to the Boise baseline and meridian. The first two segments of a number designate the township and range. The third gives the section number, followed by two letters and a numeral, which indicate the quarter section, the 40 -acre tract, and the serial number of the well within the tract. Quarter sections are lettered a, b, c, and d in counterclockwise order, from the northeast quarter of each section (see diagram). Within the quarter sections 40acre tracts are lettered in the same manner. The digits following the letters indicate the order in which the wells were first visited within the 40 -acre tracts.

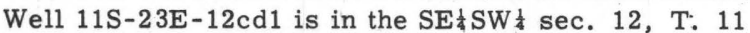
S., R. 23 E., and is the well first visited in that tract.

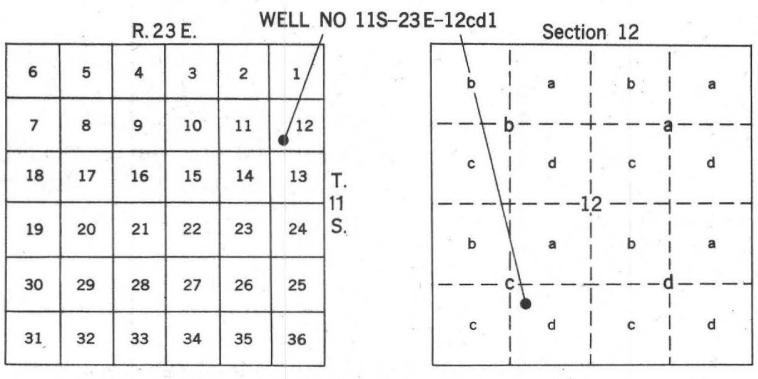

\section{Acknowledgments}

Many well owners, the R. C. Commons Drilling Co., Hittleston and Haynes Co., and A. J. Schoonover and Sons, well drillers, supplied well logs and other data. The Idaho Power Co. furnished power-consumption data on irrigation pumps. The assistance and cooperation of these individuals and companies have been of great value and are gratefully acknowledged.

\section{PHYSIOGRAPHIC HISTORY AND DRAINAGE}

The extreme southern part of Minidoka County is a relatively flat stream terrace (herein called the $\mathrm{Ru}-$ pert terrace, see fig. 1), about 18 miles long and 11 miles wide. The terrace, a local feature in the Snake River Plain, is bounded on the north and west by an escarpment 50 to 75 feet high, and on the south by the Snake River. The southern part of the county north of the escarpment is gently rolling terrain that is typical of the Snake River Plain. The North Side Pumping Division is immediately north and west of the escarpment on the rolling plain. In the vicinity of the project the generally flat to rolling surface of the plain is modified by dry gulches, shallow undrained depressions, and small knolls. A few rounded volcanic hills, having long, gentle slopes, rise one hundred to several hundred feet above the general level of the plain. The most prominent of the volcanic hills is Kimama Butte ("Big Kim"), near the northwest corner of the project. The soil of the North Side Pumping Division consists of loose or lightly compacted windblown material, which is anchored at most places by native vegetation. Clearing and plowing make the land vulnerable to wind erosion. Eastward from the town of Minidoka are active sand dunes. Water erosion is inconsequential except along a few short gullies.

In past geologic time the sedimentary and volcanic rocks in the area now occupied by the Snake River Plain were warped and faulted to form a large troughlike depression in which numerous lava flows accumulated. Between these flows, which solidified to form basalt, beds of lake, stream, and windblown sedimentsiwere deposited.

At one time, late in the period of accumulation of basalt and associated sediments, the Snake River occupied a wide, deep valley in southern Minidoka County and adjacent areas. Behind a lava dam in this valley a lake was impounded, covering much or all of the area that is now in the North Side Gravity Division. The lake basin was largely filled with sediments and a few intercalated basalt flows. The lake was drained as the Snake River cut its outlet downward, and after disappearance of the lake the Snake River deposited on the lake beds a sheet of older alluvium which now forms an extensive terrace, the Rupert terrace. Volcanic activity in the area continued during alluvial deposition but ended with the extrusion of a basalt flow (Minidoka basalt) along the north side of Lake Walcott. Younger alluvium was deposited thereafter. Deposition of windblown sediment occurred throughout the period of volcanism and continued to comparatively recent time, forming a discontinuous mantle of silt and fine sand on the basalt in much of the plain.

The Snake River Plain slopes southward and southwestward about 23 feet per mile in the Minidoka area. The average altitude along the south side of Craters of the Moon National Monument, north of Minidoka County, is about 5, 380 feet above mean sea level; along the Snake River at the southern boundary of the county the average altitude is about 4,150 feet. Owing to the gentle slope of the plain, the small amount of precipitation, and the high moisture-retention capacity of soil which overlies relatively porous basalt, runoff on the plain is small and ephemeral. An integrated drainage system has not developed because most precipitation either restores soil moisture, becomes ground-water recharge, or evaporates. Several drainage canals in the Rupert terrace downstream from Minidoka Dam collect irrigation waste water and discharge into the Snake River. Some waste water drains into intake wells and recharges the regional aquifer.

\section{CLIMATE}

Minidoka County has moderately cold winters and warm summers. The mean annual temperature at Rupert is $47.6^{\circ} \mathrm{F}$ (table 2). The climate is moderated by prevailing westerly winds from the Pacific area, 
Table 2. - Mean annual temperature and normal annual precipitation at eight stations on the Snake River $\underline{\text { Plain }}$

[From records of U. S. Weather Bureau]

\begin{tabular}{r|c|r|r|r}
\hline & $\begin{array}{c}\text { Years } 1 / \\
\text { of } \\
\text { record }\end{array}$ & $\begin{array}{c}\text { Altitude } \\
\text { (feet above } \\
\text { mean sea } \\
\text { level) }\end{array}$ & $\begin{array}{c}\text { Precipi- } \\
\text { tation } \\
\text { (inches) }\end{array}$ & $\begin{array}{c}\text { Temper- } \\
\text { ature } \\
\left({ }^{\circ} \mathrm{F}\right)\end{array}$ \\
\hline Richfield.... & 40 & 4,306 & 9.73 & 45.0 \\
Shoshone... & 46 & 3,968 & 10.23 & 47.0 \\
Hazelton.... & 38 & 4,060 & 10.72 & 49.4 \\
Burley fac- & & & & \\
tory....... & 30 & 4,200 & 10.00 & 47.3 \\
Burley...... & 37 & 4,180 & 9.39 & 48.7 \\
Burley CA. & 17 & 4,157 & 9.26 & 47.7 \\
airport.... & 20 & 4,200 & 10.34 & 48.0 \\
Paul.......... & 48 & 4,204 & 9.95 & 47.6 \\
\hline Rupert...... & 48
\end{tabular}

1/ Includes some years of fragmentary records.

and the region is sheltered from northern cold waves by the Continental Divide. The average length of the growing season for hardy crops is about 190 days; the average frost-free period is about 130 days.

Precipitation in the southern part of the county is about 8 to 10 inches a year, of which less than 40 percent falls during the growing season (tables 2 and 3 ). Precipitation is lowest in July, August, and September (table 3 ). Irrigation is essential for a stable farming economy.

Table 3. - Normal monthly and annual precipitation at Rupert, 1907-53

[From records of U. S. Weather Bureau]

\begin{tabular}{|c|c|c|}
\hline Month & $\begin{array}{c}\text { Precipitation } \\
\text { (inches) }\end{array}$ & $\begin{array}{c}\text { Percent } \\
\text { of annual } \\
\text { total }\end{array}$ \\
\hline January............... & 1.06 & 10.65 \\
\hline February............ & .95 & 9.55 \\
\hline March............. & .78 & 7. 84 \\
\hline April............... & 1.02 & 10.25 \\
\hline May...................... & 1.01 & 10.15 \\
\hline June....................... & .84 & 8.44 \\
\hline July........................ & .41 & 4.12 \\
\hline August...................... & .41 & 4.12 \\
\hline September................. & .56 & 5.63 \\
\hline 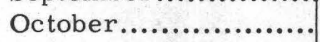 & .94 & 9.45 \\
\hline November................ & 1.00 & 10.05 \\
\hline December............... & .97 & 9.75 \\
\hline Annual.................. & 9.95 & 100 \\
\hline
\end{tabular}

The average relative humidity in the area is slightly less than 56 percent. The average monthly evaporation from a class A landpan operated by the Weather Bureau at Minidoka Dam was 9.8 inches during the period May to October. The rate of evaporation varied from 6.0 inches in October to 12.2 inches in August.
Sustained wind velocities of 15 to 20 miles per hour are common on the Snake River Plain, but gusts reach much higher velocities. Wind erosion occurs wherever the native sod is broken and left unprotected. Winds of destructive force, however, are rare. Summer thunderstorms occur infrequently and usually are mild. Losses from lightning are negligible. Hailstorms occasionally strike the area, but these storms generally are limited in extent and seldom are damaging.

\section{AGRICULTURAL DEVELOPMENT}

Minidoka County had about 10,000 inhabitants in 1950, according to the U. S. Census of Population, and about a third of the population lived in Rupert. Other small villages and their 1950 population are Paul, 600; Heyburn, 413; Minidoka, 200; and Acequia, 75. The county contained 1,059 farms, comprising 123,334 acres, or 26 percent of the total county area. The number of farm acres increased from 75,174 in 1945 to 123,334 in 1950 , and the average size of farms increased from 76 to 116 acres. Ninety-six percent of the farms, covering 103,472 acres, were irrigated in 1950 , according to the U. S. Census of Agriculture.

Agricultural products of the county include alfalfa, beans, potatoes, sugar beets, cereals, seeds, dairy products, beef, mutton, and wool. Industries in the area are closely related to agriculture and include milk-processing plants, a sugar factory, and seed and potato warehouses.

Rupert, the county seat of Minidoka County, is served by a branch of the Union Pacific Railroad, by U. S. Highway 30 , and by State Highway 25. Two motor freight lines and a bus line pass through the town and air transportation is available 8 miles south of Rupert at the Burley airport.

\section{Surface Water}

The principal use of surface water in the Minidoka North Side area is for farm irrigation and yard watering in towns. The main source of irrigation water for the Gravity Division is the Snake River, the diversion being made at Minidoka Dam. Supplemental water is stored in upstream reservoirs. Storage in Lake Walcott is drawn on in years of very low water supply, but lake storage is primarily for power generation. The earliest delivery of water to the Gravity Division was in 1907, and facilities for delivery of gravity water were completed by 1917 . The average amount of water diverted to the project during the period 194.3-53 was about 450,000 acre-feet a year. Surface water is also used to irrigate about 50,000 acres of the South Side Pumping Division (Burley Irrigation District); water was first available for these lands in 1908. Small quantities are required for stock and industrial uses.

\section{Ground Water}

Rupert, Paul, and Minidoka have municipal wells. The Union Pacific Railroad Co., a cheese factory, and a potato warehouse have their own wells. A sugar refinery at Paul utilizes both ground water and surface water for processing sugar beets. Most rural and suburban homes obtain water for domestic use from wells. 
Pumping ground water for irrigation in Minidoka County was begun in 1947 by the Julian Clawson Farms, Inc., to irrigate land in the southeast part of T. $7 \mathrm{~S}$. , R. $23 \mathrm{E}$. In 1948 the Bureau of Reclamation drilled three large-bore test wells and thereafter leased these wells with appropriate land parcels to private interests. The success of leased farms demonstrated the general feasibility of ground-water irrigation in the proposed Pumping Division. By the end of 1953, 11 irrigation wells were operating in the Pumping Division, and about 125 private irrigation wells had been drilled on private land nearby. The progress of ground-water development in the area is summarized in table 4. Two hundred or more additional wells may be drilled before development of the project and adjacent private land is complete.

Table 4. -Ground-water development in the Minidoka area

\begin{tabular}{|c|c|c|c|}
\hline Year & $\begin{array}{c}\text { Number, } \\
\text { of } \\
\text { wells }\end{array}$ & $\begin{array}{c}\text { Estimated } \\
\text { pumpage } \\
\text { (acre-feet per year) }\end{array}$ & $\begin{array}{c}\text { Estimated } \\
\text { area irrigated } \\
\text { (acres) }\end{array}$ \\
\hline $1947 \ldots$ & 3 & & \\
\hline $1948 \ldots$ & 6 & & \\
\hline $1949 .$. & & & \\
\hline $1950 \ldots$ & 30 & 28,000 & 9,700 \\
\hline $1951 \ldots$ & 92 & 68,000 & 23,800 \\
\hline $1952 \ldots$ & ........... & 72,000 & 25,000 \\
\hline $1953 \ldots$ & 136 & 79,000 & 26,000 \\
\hline
\end{tabular}

Other areas in the Snake River Plain, north and east of the Pumping Division, also are being reclaimed with ground water, and the estimated amount of groundwater utilization in these areas is about 245,000 acrefeet a year (table 5). Although the tables do not show all pumping developments on the plain, they suggest the current order of magnitude. Other large developments are in prospect in various parts of the plain.

Table 5. - Estimated ground-water pumpage for irrigation northeast of the Minidoka area, 1953

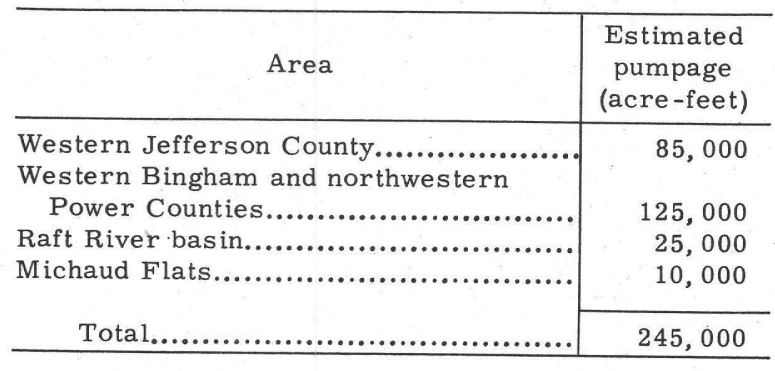

\section{GEOLOGIC FORMATIONS AND THEIR WATER- BEARING PROPERTIES}

The geologic formations in the area differ markedly in their water-bearing properties. The materials in them range from highly permeable to nearly impermeable. Permeability influences the rate at which the materials accept recharge, transmit water, and yield water to wells. The physical characteristics, the areal distribution, and the water-bearing properties of the geologic units are summarized in table 6 . Their surface distribution is shown on the geologic map (fig. 1). The Burley lake beds do not crop out in the map area but are present at depth.

\section{Younger Alluvial and Windblown Deposits}

Windblown silt, sandy clay, and very fine sand mantle most of the volcanic rock in the area and are mixed with alluvium in the deposits beneath the Rupert terrace. The thickness of the windblown material is as much as 50 feet. Beneath much of the area a weakly cemented "hardpan" occurs at depths of 2 to 6 feet in the windblown deposits. These deposits are above the zone of saturation and therefore are not water bearing. The windblown material has a moderately high moistureretaining capacity, but its permeability is sufficient to allow downward percolation of water. The "hardpan" layers impede percolation.

The younger alluvium, which is restricted to the flood plain and channel of the Snake River, consists of poorly sorted deposits of clay, silt, sand, and clean, water-worn gravel derived mostly from reworked older alluvium. The alluvium contains abundant ground water at shallow depth, but because of its limited areal extent and thickness it is not an important aquifer. On the geologic map the younger alluvium is not differentiated from the older alluvium.

\section{Minidoka Basalt}

The Minidoka basalt (Stearns, 1938), which is exposed along the north shore of Lake Walcott, is blue black to dark gray and vesicular. The basalt seemingly originated from cones northeast of Minidoka. Joints and other fractures in the basalt make it quite permeable, and near Lake Walcott the lower part of the formation contains ground water that is recharged by percolation from the lake.

\section{Older Alluvium}

Older alluvium underlies the Minidoka basalt and forms the Rupert terrace. The alluvium is chiefly silt and sand, but gravel occurs at some places, especially in the lower part of the formation. It overlies the Burley lake beds, with which its contact may be gradational. Sand and gravel beds in the older alluvium are a principal source of unconfined shallow ground water for domestic, stock, and industrial use in the Gravity Division.

\section{Burley Lake Beds}

The ancient lake in which the Burley lake beds were deposited covered the area of the Gravity Division but apparently did not extend into the Pumping Division. The beds are known only from well cuttings, which show that they occur beneath older alluvium in the Gravity Division. On the basis of the log of a deep municipal well in Burley, Stearns (1938) applied the name Burley lake beds to deposits between 15 and 150 feet below the land surface; he did not include in the 
Table 6.-Geologic formations and their hydrologic properties

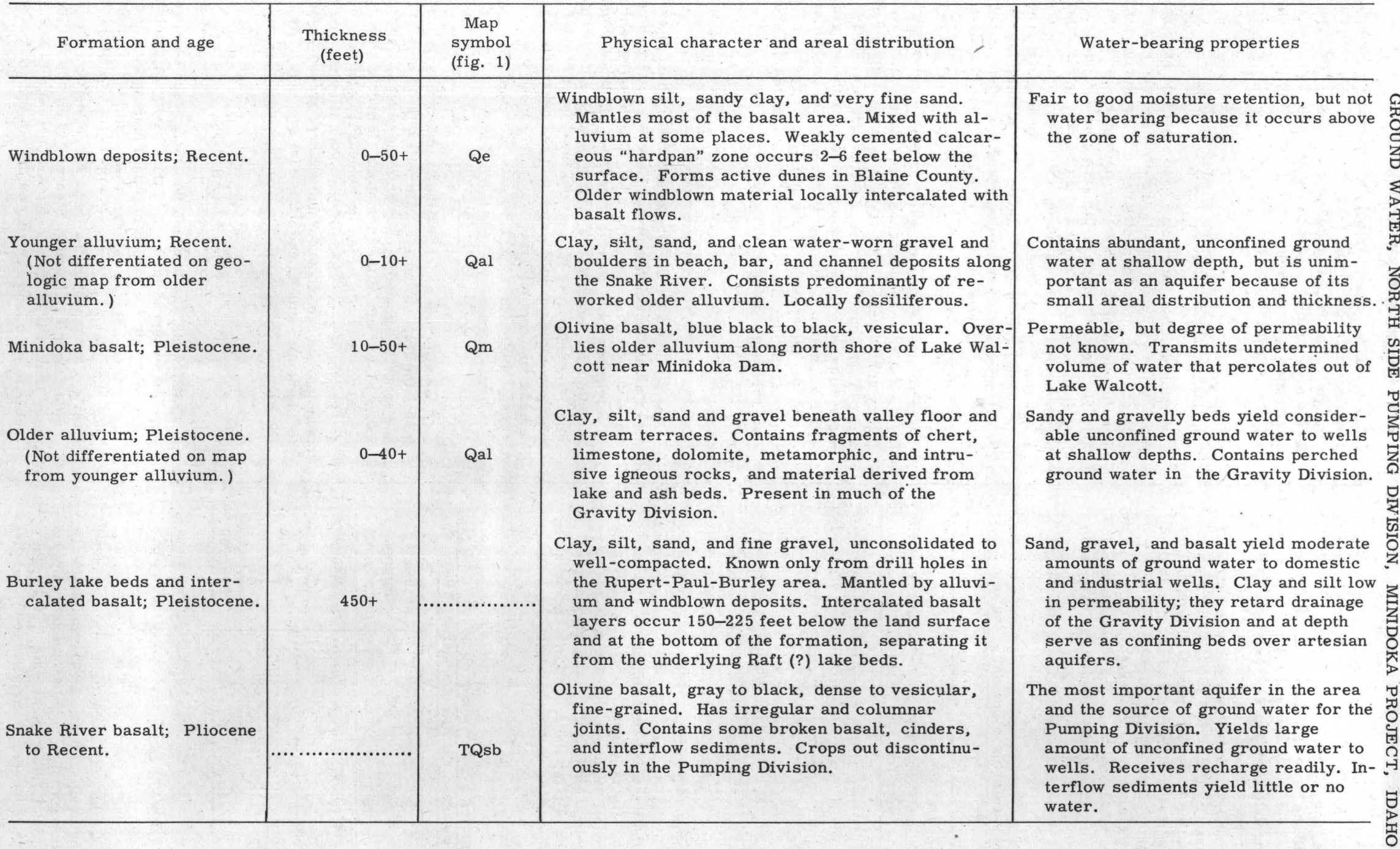


unit a deeper sequence of similar deposits between 225 and 475 feet below the surface in the Burley well, underlying a thin layer of basalt. The deeper lake deposits were tentatively considered as a westward extension of the Raft lake beds, because of their similar stratigraphic positions above a 650 -foot sequence of volcanic rocks that were penetrated by the Burley city well. The Raft lake beds are exposed along the south shore of Lake Walcott as far west as the mouth of Raft River (about 12 miles east-southeast of Minidoka Dam), where they dip westward about 18 feet per mile. If this dip were maintained westward the beds would lie about 550 feet below the land surface at Burley. The difference between this depth and the actual depth of the beds at Burley was inferred by Stearns to be a result of faulting along the west side of the Raft River.

On the north side of the Snake River the Rupert municipal well (9S-24E-29ad1), and the Amalgamated Sugar Co. well 2 (9S-23E-27bd1) near Paul, penetrate lake beds at depths between 550 and 575 feet. These sediments are more sandy and the clay layers are lighter in color than the shallow lake beds. The two sequences of lake beds are separated by about 135 feet of basalt and nonlacustrine sediments. The third and deepest group of lake beds resembles the Raft lake beds more closely than do the others, and the depth to the third group at Rupert and Paul is more conformable with their dip in outcrop areas. The absence of the third group in the Burley municipal well can be explained by nondeposition or removal by erosion before emplacement of the basalt in the Burley area. For the purposes of this report all lake sediments beneath the alluvium to a depth of about 475 feet are grouped with the Burley lake beds.

The Burley lake beds, as here defined, consist of about 450 feet of compacted to unconsolidated clay and silt, and small amounts of sand and fine gravel. Several basalt layers are intercalated in the lake beds 150 to 225 feet below the land surface and at the base of the formation. The sand, gravel, and basalt are permeable and yield moderate amounts of ground water to domestic, municipal, and industrial wells. The clay and silt beds are very low in permeability and are the base on which shallow ground water is perched in overlying alluvium. At depth these impermeable beds confine artesian water in associated permeable sediments.

\section{Snake River Basalt}

The Snake River basalt underlies all of the Minidoka area and most of the Snake River Plain. At most places in the area of proposed ground-water development the basalt is overlain by 2 to 50 feet or more of windblown deposits, but small outcrops are common (fig. 1). In Minidoka County and most other parts of the Snake River Plain the Snake River basalt is the principal water-bearing formation, and it yields water copiously to wells. Intertongued sedimentary beds are saturated below the water table but yield little or no water to wells.

The Snake River basalt consists of many individual flow sheets, 10 to 75 feet thick, which originated at numerous volcanic vents scattered over the Snake River Plain. At some places, where lava flowed into former stream channels, the flow layers are much thicker and highly irregular. A few sedimentary beds are intercalated in the basalt. The total thickness of the basalt is rot known. In southern Minidoka County wells 500 feet deep end in basalt.

The rock is predominately olivine basalt, occurring chiefly as dense to vesicular layers having smoothly billowed surfaces. Locally, the basalt surfaces are corded and "ropy". Broken, blocky basalt is uncommon in the Minidoka area. Most of the rock is various shades of gray, but purple, red, and black colors are not rare and color differences are common within individual flows.

Much of the basalt, especially in thick flows, has the characteristic columnar jointing that is produced by shrinkage during cooling. Contacts between many basalt layers are highly irregular; many open spaces occur where rapid chilling and solidification of the upper flow caused granulation and brecciation or prevented close molding to the configuration of the lower flow surface. The open vertical cracks and joints impart high vertical permeability to some layers. On the other hand, some flows are massive, solid, and low in permeability.

\section{WATER RESOURCES}

\section{Source and Disposition of Water}

The ultimate source of practically all ground water is precipitation. Some precipitation is evaporated, some runs off from the land surface, and some restores soil moisture. The residual water is available for ground-water recharge. Natural discharge of ground water occurs through springs and seeps and by evapotranspiration. Most precipitation in the Minidoka area that is not used to restore soil moisture becomes ground-water recharge because natural surface runoff is very small. All natural local surface drainage is ephemeral. Numerous drainage ditches discharge surface-waste water from the irrigation system and also tap ground water where the drains intercept shallow perched water. Some drains discharge by gravity or pumping into the Snake River. Others discharge into drainage (intake) wells that conduct the water underground. Natural discharge from the main body of ground water is chiefly through springs in the Snake River valley, 20 to 50 miles west of the Pumping Division.

The upstream part of Lake Walcott is continuous with the zone of saturation in adjacent rocks, from which ground water is discharged into the lake. The downstream part of the lake seemingly is perched above the main water table for a distance of about 9 miles above Minidoka Dam. In the early period of reservoir operation the relations of the lake to ground water apparently were somewhat different, because a great deal of water was lost by percolation into the ground. The average yearly volume of water lost during the period 1907 to 1910 was about 428,000 acre-feet; during the middle 1920's the loss was only about 107,000 acre-feet a year (Stearns, 1938). Currently there is an ungaged net gain to Lake Walcott of about 82,000 acrefeet a year (table 7). Reduction of the net percolation loss probably is caused in part by a natural seal of silt and clay on the floor of the reservoir. Also, the lake level is not. as high as it formerly was. The upstream part of the lake now gains more ground water that it formerly did; such inflow probably exceeds 
Table 7. - Inflow, outflow, and ungaged net gain in storage in Lake Walcott, 1950-53

[Acre-feet per year. Based on records of Water District 36, Snake River, Idaho]

\begin{tabular}{|c|c|c|c|c|c|c|c|c|}
\hline \multirow[b]{2}{*}{$\begin{array}{l}\text { Water } \\
\text { year }\end{array}$} & \multicolumn{3}{|c|}{ Inflow } & \multicolumn{4}{|c|}{ Outflow } & \multirow[b]{2}{*}{$\begin{array}{l}\text { Net } \\
\text { gain }\end{array}$} \\
\hline & $\begin{array}{c}\text { Snake River } \\
\text { at Neeley }\end{array}$ & $\begin{array}{c}\text { 1/ Ungaged } \\
\text { surface } \\
\text { inflow } \\
\text { (estimated) }\end{array}$ & Total & $\begin{array}{c}\text { Snake River } \\
\text { near } \\
\text { Minidoka }\end{array}$ & $\begin{array}{c}\text { Minidoka } \\
\text { diversion } \\
\text { canals }\end{array}$ & $\begin{array}{l}\text { Evaporation } \\
\text { (estimated) }\end{array}$ & $\begin{array}{c} \\
\text { Total }\end{array}$ & \\
\hline $1950 \ldots$ & $6,180,700$ & 55,000 & $6,235,700$ & $5,552,100$ & 791,670 & 30,000 & $6,373,770$ & 138,070 \\
\hline $1951 \ldots$ & $6,890,900$ & 55,000 & $6,945,900$ & $6,181,900$ & 817,600 & 30,000 & $7,029,500$ & 83,600 \\
\hline $1952 \ldots$ & $7,384,800$ & 55,000 & $7,439,800$ & $6,568,800$ & 841,298 & 30,000 & $7,440,098$ & 298 \\
\hline $1953 \ldots$. & $4,918,970$ & 55,000 & $4,973,970$ & $4,254,430$ & 795,575 & 30,000 & $5,080,005$ & 106,035 \\
\hline Average & $6,343,842$ & 55,000 & $6,398,842$ & $5,639,310$ & 811,536 & 30,000 & $6,480,842$ & 82,000 \\
\hline
\end{tabular}

1/ Includes Rock and Fall Creeks, Raft River, and springs along north side of Snake River between Raft River and Neeley.

downstream loss by percolation and is the source of the ungaged net gain to Lake Walcott.

\section{Ground Water}

\section{Sources, Occurrence, and Movement}

The unified body of ground water in the Snake River Plain is replenished perennially from several sources: (1) direct infiltration of precipitation; (2) mass underflow from adjoining highlands; (3) underfiow from tributary valleys; (4) infiltration from surface streams; (5) infiltration of unconsumed irrigation water. The gross volume of ground-water recharge from precipitation directly on the Snake River Plain may be large, but the amount per unit area is very small at most places, owing to the low rate of precipitation. On the Minidoka project direct infiltration of precipitation to the ground-water body occurs chiefly in areas of exposed permeable basalt where there is little or no soil to absorb moisture. Important local replenishment of ground water in the Snake River basalt is by percolation from Lake Walcott and by the underflow of the perched ground water in the Rupert terrace.

Little is known about quantities of water contributed to the basalt aquifer from individual sources on the Snake River Plain. The ground water from all sources moves generally westward by underflow and is discharged from springs in the Snake River valley. The Pumping Division is at the center of the southern edge of this ground-water body. Thus, although increments of ground water from local sources are comparatively small, wells in the reclamation area tap a supply maintained by large contributions from outside the Minidoka area.

The approximate position of the main water table in the vicinity of the Pumping Division is shown on plate 1. A perched water table occurs in the southern part of the map area where ground water in alluvium of the Rupert terrace is recharged by percolating irrigation water. The perched water table is not shown on the map, but the area of perching coincides approximately with the area occupied by Quaternary alluvium in the Rupert terrace (fig. 1). The contours of the main water table are tentatively extended only a short distance beneath the area of perched water (pl. 1).
The direction of ground-water flow is west and southwest, about at right angles to the water-table contours. Local recharge from Lake Walcott and the Gravity Division causes local variations in the form of the water table and the direction of the gradients. The gradient of the water table averages about 3 feet per mile beneath most of Unit B of the Pumping Division, but under the western part of the Division the gradient steepens to about 12 feet or more per mile. Local differences in the gradient probably are caused by differences in the permeability of the basalt and by the presence of nonpermeable fine-grained sediments intercalated with the basalt. Some differences may be influenced by the shape and slope of the impermeable floor beneath the main zone of saturation and by local differences in the rate of recharge and replenishment.

\section{Water-Table Fluctuations}

Water-table changes in general reflect changes in the amount of ground water in storage, although some momentary and short-term fluctuations are caused by special factors such as earthquake shocks. A general annual rise and fall of the water table occurs during the annual cycle of ground-water recharge and discharge. The downward trend usually commences in October and the rise usually begins in April or May.

During the period of this investigation, 14 automatic water-stage recorders were operated on observation wells in the area, and periodic measurements of water levels were made in 12, additional observation wells (pl. 1). Water-level fluctuations in representative wells are illustrated graphically in figures 4 and 5 , which clearly show the yearly rise and fall of the water table.

Well 9S-24E-1db2, on the Rupert terrace near its north edge, is directly and strongly influenced by surface-water irrigation on the Gravity Division. Well $9 \mathrm{~S}-25 \mathrm{E}-23 \mathrm{db} 1$ may be affected by irrigation, by seepage from Lake Walcott, and by underflow from the Raft River valley. Other wells represented in figures 4 and 5 are in or near the pumping project and their water-level fluctuations are typical of those throughout the area of proposed ground-water development. 


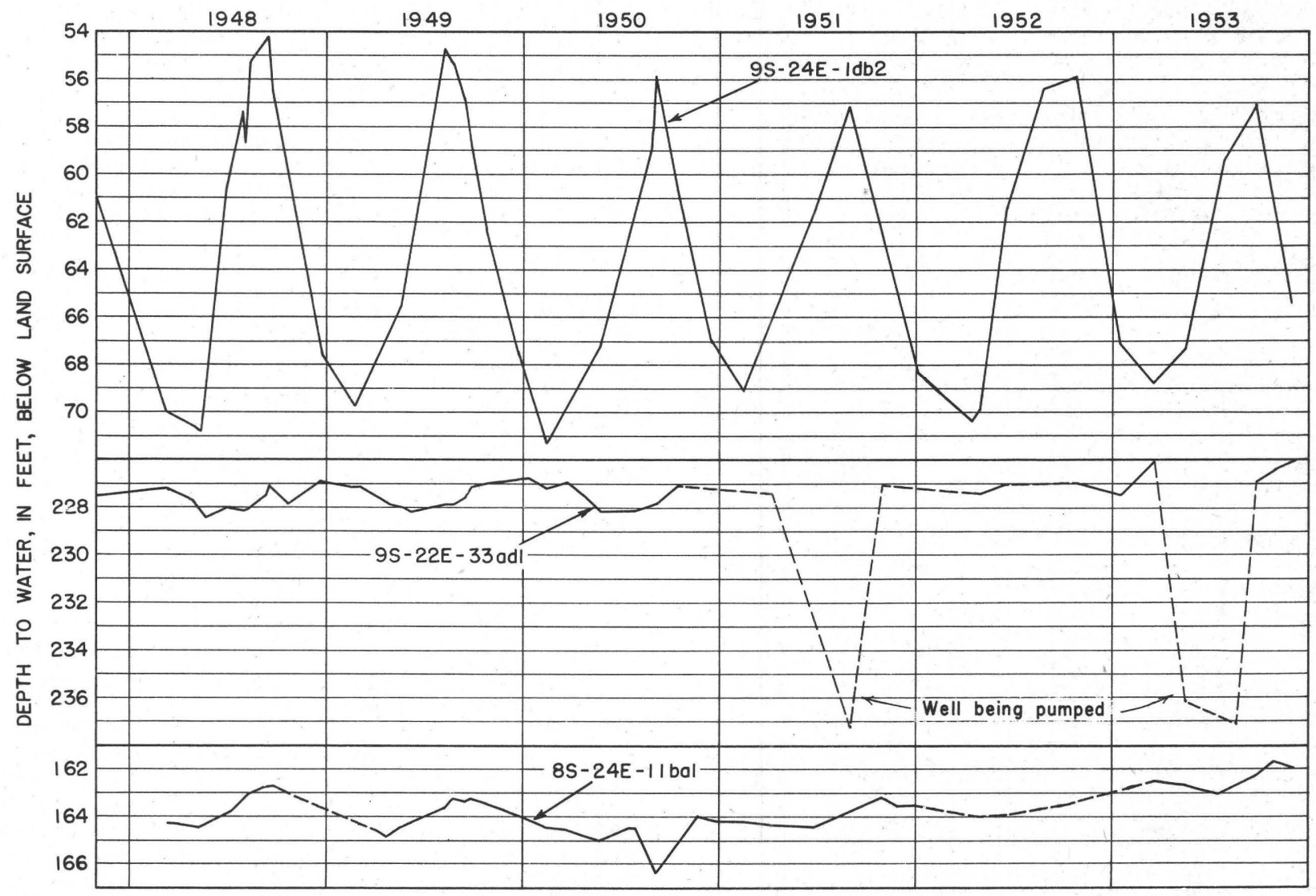

Figure 4. -Water-level fluctuations in wells in Minidoka County, 1948-53.

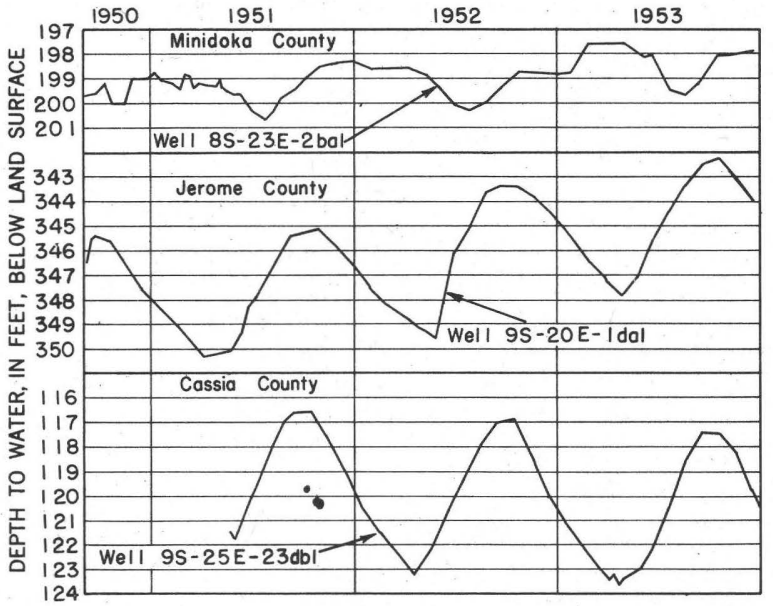

Figure 5.-Water-level fluctuations in wells in the Minidoka project, 1950-53.

The annual range of fluctuations in the basalt aquifer is about 1 to 5 feet and the average is about 2 feet. Longer-term water-level trends and net changes are disclosed by records for the period 1948-53.
Since 1948 a net rise of 0.5 to 3 feet in the water levels in most wells that tap the main basalt aquifer occurred. In well $9 \mathrm{~S}-24 \mathrm{E}-1 \mathrm{db} 2$ (fig. 4) there was an apparent net decline of about 2.5 feet. This well is in the irrigated area at Acequia and the decline, might have been caused partly by reduced recharge during recent years of less abundant diversions of surface water for irrigation. Also, the well is measured only six times a year and the actual maximums and minimums may not have been detected. In well 9S-25E$23 \mathrm{db} 1$, which taps water in basalt south of the Snake River, there has been a net decline of about a foot in the water level. Water at that location is replenished largely by underflow from the Raft River basin. Underflow probably has been reduced owing to deficient recharge during recent years of subnormal precipitation in the Raft River basin. Underflow from that basin also may influence water levels in the vicinity of Acequia. The length of the period of observations is not sufficient to warrant analytical conclusions at this time. The short-term effects of local pumping are small and difficult to detect in wells that tap water in the main basalt aquifer. In the highly permeable Snake River basalt the drawdown caused by pumping ordinarily is small, and the slope of the cone of influence is so slight that water-level changes can be detected readily only in wells close to a pumped well. 
Water levels in most wells fluctuate in response to changes in atmospheric pressure. Figure 6 compares the hydrograph of well $8 \mathrm{~S}-23 \mathrm{E}-2 \mathrm{ba} 1$ with the inverted barometer readings at the Burley station of the U. S. Weather Bureau, from March 29 to April 9, 1953. Barometric fluctuations in water levels must be recognized in hydrographs before the graphs can be interpreted properly, especially in pumping tests where observed water-level fluctuations are small and are used in the calculation of hydraulic constants of aquifers.

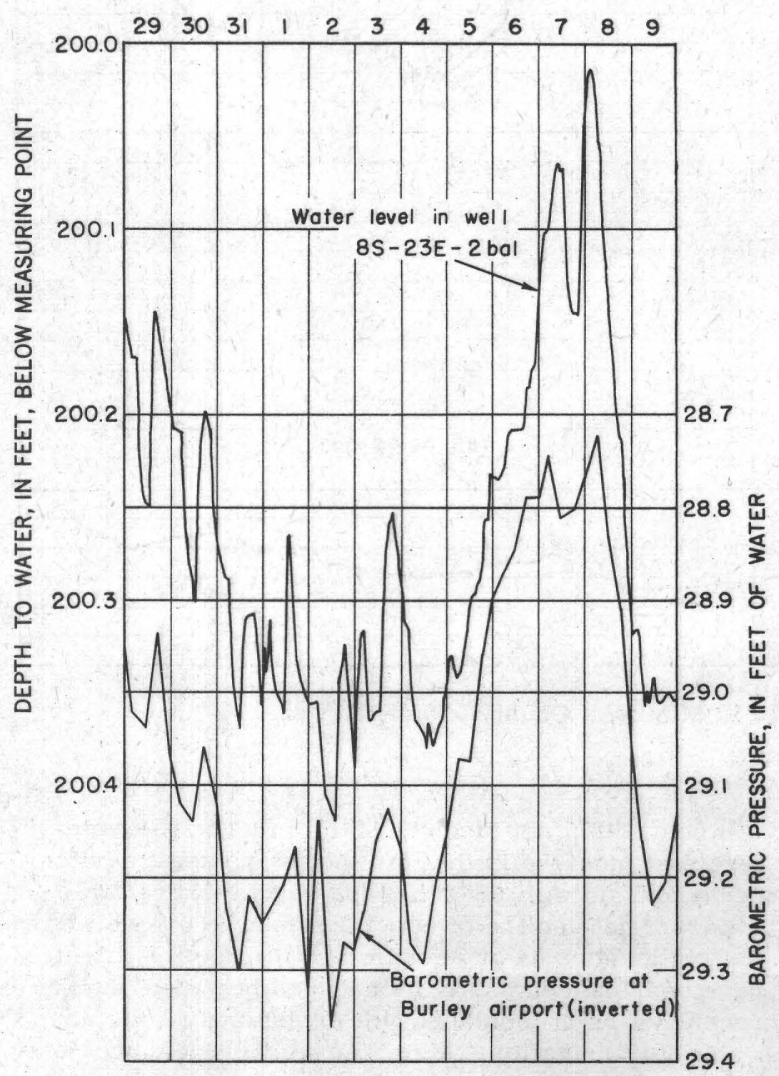

Figure 6.-Graphic comparison of water-level fluctuations in well $8 \mathrm{~S}-23 \mathrm{E}-2 \mathrm{ba1}$ with barometric pressure at Burley, March 29-April 9, 1953.

\section{Total Water Supply}

The average annual ground-water yield of the Snake River basalt constitutes the supply that is perennially available for use. Practically the entire yield of the regional aquifer east of Bliss presumably is discharged through the springs in the Snake River valley above Bliss. Therefore, the aggregate average annual discharge from these springs is an approximate measure of the unused ground water perennially available. During several recent years the estimated annual discharge of the springs was about 4.5 million acre-feet (Crandall, 1953). That amount is somewhat greater than the long-term average because the amount of precipitation on the plain was somewhat greater than average for about 10 preceding years. Moreover, available records do not clearly segregate spring discharge from irrigation waste in the vicinity of the springs, or from the discharge from springs and drains on the south side of the Snake River.

For the purposes of this report the yield of the springs is assumed to be 4.0 million acre-feet a year. The total ground-water yield of the basin could not, of course, be removed by wells during the pumping season.

Underflow of shallow ground water from the Rupert terrace to the regional water table in the Pumping Division was estimated to be about 233,000 acre-feet annually in 1928 (Stearns and others, 1938). The present volume of underflow probably is about the same. Underflow from the Raft River valley also probably contributes at least a few thousand acre-feet of water annually to the aquifer in or near the Pumping Division. A large amount of water enters the ground by percolation from Lake Walcott. Thus, in the vicinity of the Pumping Division, there are large sources of groundwater replenishment independent of plains-wide sources of replenishment to the regional ground-water body.

Ground water that reaches the aquifer in the Pumping Division from local sources obviously amounts to at least a few hundred thousand acre-feet a year. Not all of this could be removed by pumping during the irrigation season. The amount of ground water in so-called permanent storage, however, is large. Heavy pumping would lower water levels locally, steepening the natural ground-water gradients toward the Division and inducing inflow of a large amount of water that otherwise would bypass the area. The amount of induced inflow cannot be estimated at this time. Assuming, however, that there are no impermeable hydraulic barriers around the Pumping Division, it seems probable that water could be pumped in an amount at least several times as great as that available from local sources.

\section{PROPOSED DEVELOPMENT}

\section{Private}

Adjacent to the east, north, and west sides of the Pumping Division, 129 private wells withdraw annually about 60,000 acre-feet of ground water from the Snake River basalt. Much of the land watered from these wells was homesteaded under the Federal Desert Land Act. Private operations in the area propose to develop about 88,500 acres of desert land, having a probable yearly gross ground-water demand of 325,000 acrefeet.

As of December 31, 1953, forty-nine well-construction permits had been issued by the Idaho State Department of Reclamation for land west of Kimama. Under these permits it is proposed to develop about 35,000 acre-feet of ground water for about 10,000 acres of desert land. As of the above date wells had not been drilled under the permits and it seems unlikely that all the proposed development will occur in the near future.

The total of existing private water-right filings for land in the vicinity of the Minidoka Division is for $1,770 \mathrm{cfs}$. 
At least several hundred thousand acres of raw land on the Snake River Plain is irrigable, and water for this land must be obtained largely from the groundwater reservoir. Complete development is not expected to occur in less than 20 to 30 years, and it may proceed at an average rate of a few tens of thousands of acres per year. Some of this development will take place in the vicinity of the Pumping Division, where it may proceed more rapidly then in other areas because of the proved permeability of the aquifer, the demonstrated efficient performance of wells, and the generally good soil. The rate of development may be influenced strongly by the prices of power and agricultural products. For present purposes it is estimated that roughly 40,000 acres of private land in the vicinity of the project may be developed within the next 10 years, and that the gross water demand of this land will be about 140,000 acre-feet a year. Thus, within 10 years the total private demand for ground water in the vicinity of the Minidoka Project may be at least 200, 000 acre-feet.

\section{North Side Pumping Division}

The original plan of the Bureau of Reclamation for the Minidoka Project was to supply water to the entire North Side Pumping Division by pumping from the Snake River into a high-line gravity canal. More recent plans (Newell, 1949) set up two units in the division, Unit A and Unit B (pl. 1). Beneath much of Unit A the depth to ground water is greater than the economically feasible pumping lift, according to studies by the Bureau of Reclarnation. Hence Unit A, containing 13,650 irrigable acres of land, would be supplied with about 59,100 acre-feet of water pumped from Lake Milner into a high-line canal. Unit B, containing 64,000 irrigable acres, would be supplied with ground water, pumped at an estimated maximum rate of 1,000 cfs from about 175 wells. The average yield of individual wells would be about $5.5 \mathrm{cfs}$, and total pumpage would be about 235, 000 acre-feet a year. The Bureau of Reclamation has filed with the State of Idaho an application for rights to $1,333 \mathrm{cfs}$ of water.

Farm units will range in size from 90 to 135 irrigable acres. In order to provide flexibility in the pumping and distribution systems, at some pumping sites two wells with different pumping capacities will be installed, and lateral canals will interconnect adjacent farms. Either or both pumps may be operated, according to fluctuations in water demand.

Development of Unit B has been accomplished on an experimental scale. During the 1953 irrigation season about 17, 250 acre-feet of ground water was pumped for 5, 170 acres of land. Starting in 1953 the rate of development was accelerated and complete development is scheduled for 1959 .

\section{Summary}

The total of private and Government filings for ground-water rights in the Minidoka Project and vicinity is for $3,103 \mathrm{cfs}$. Unit B of the North Side Pumping Division ultimately will require about 235,000 acre-feet of ground water each irrigation season. Private development adjacent to Unit B probably will require, within the next 10 years, about 200,000 acre- feet a year, including the 60,000 acre-feet a year now being pumped. Development of all suitable land in the Minidoka area outside of Unit B ultimately might require about 325,000 acre-feet of ground water annually. Assuming that the net consumptive use of irrigation water will be 1.8 acre-feet per acre, the foreseeable net ground-water depletion will be about 275, 000 acrefeet a year-115,000 in Unit B and 160,000 in the adjacent area. The probable net depletion by existing and new developments north and east of the Minidoka project may be roughly 350,000 acre-feet. The present and proposed development of all irrigation projects, Federal and private, on the Snake River Plain east of Bliss, ultimately probably will deplete the ground water by two times that amount or more. An increase or decrease of water use in any one area will affect the water levels in all the other areas directly or indirectly, because of the high coefficient of transmissibility of their common aquifer. Each depletion also will affect the discharge of the springs in the Snake River valley.

Depletion of the existing supply of ground water will be offset to some extent by new recharge from surfacewater irrigation in Unit A. The Bureau of Reclamation plan for Unit A is to supply 13,650 acres with 4 . 33 feet of water pumped from the Snake River above Milner Dam. The total volume of pumped surface water will be about 59, 100 acre-feet a year, of which about 24,500 acre-feet ( 1.8 acre-feet per acre) will be used consumptively on the land. Surface water returned to the river as waste is expected to amount to about 4,600 acre-feet. The unconsumed residual water, about 30,000 acre-feet, will percolate downward and recharge the aquifers. The new recharge would occur down the ground-water gradient from Unit B and would not be intercepted directly by pumped wells there. Nevertheless, the regional reservoir would be replenished, reducing net depletion of the ground water and helping to sustain the flow of springs in the Snake River valley.

Palisades reservoir, now under construction, will provide supplemental surface water to land already under irrigation, as well as a total supply for some new land. Ground-water recharge from irrigation on the plain will be increased and will partly offset regional depletion of ground water. During dry years a more nearly normal supply of surface water will be available for irrigation, thus helping to maintain ground-water recharge at a more constant rate.

\section{LIMITING AND CONTROLLING HYDROLOGIC FACTORS}

Detailed analysis of limiting and controlling economic factors is beyond the scope of this report, which is concerned chiefly with hydrologic factors. The principal hydrologic factors limiting and controlling the feasibility of developing ground water for the Minidoka North Side Pumping Division are (1) availability of an adequate unappropriated water supply in the main aquifer, (2) the capacity of the aquifer to yield the water and transmit it from the regional body of ground water to the local sources of withdrawal, and (3) the local and regional effects of sustained heavy pumping. These factors affect both the physical and economic feasibility of ground-water pumping. The capacity and efficiency of wells also are important factors. 


\section{Availability of Ground Water}

Part of the 4 million acre-feet of water discharged annually from the Snake River basalt by springs in the Snake River valley is used for irrigation, power, public supplies, and industry. New uses of water that deplete spring flow may infringe on established rights.

The total gross water requirement for the North Side Pumping Division and for adjacent competing lands having water rights and licenses is about $3,103 \mathrm{cfs}$. The net depletion of ground water by consumptive use on these lands will be about 275,000 acre-feet (see p. 13). Some upgradient ground-water rights on the Snake River Plain have equal or earlier priority, but some priorities are later and new licenses would have later priority dates. Hence, it is assumed here that the water rights of the Pumping Division will be equal to or better than most other ground-water rights dated since 1947. If all of these rights are proved up, the estimated total volume of ground-water depletion (consumptive use on irrigated land) will not exceed 500,000 acre-feet, or about 12.5 percent of the yearly discharge of the springs in the Snake River valley. Much of the existing development is on or near the south border of the central basalt plain, and springs in the upstream part of the Snake River valley may be affected more than those in the downstream part by existing and proposed ground-water withdrawals. Segregation of the effects of most individual or unit-group withdrawals on spring discharge cannot be determined. It is anticipated, however, that a 12.5-percent depletion will not infringe seriously on present water use at the springs or on surface-water rights downstream from the springs. If adverse effects occur they probably will be most noticeable at State and Federal fish hatcheries and at hydropower plants that use water directly from large springs.

\section{Capacity of Reservoir Rocks}

The phenomenal water-bearing capacity of the Snake River basalt is well established and widely known. Thus, small developments at suitable locations on the plain involve little uncertainty. The hydraulic properties of the Snake River basalt, however, are not well understood, and it is doubtful that the common hydraulic coefficients of transmissibility and storage can be derived or used in the same way they are for common sand and gravel aquifers. Thus, few calculations have been made of the apparent coefficient of transmissibility of the Snake River basalt, and the reliability of the calculations is not known. The tests and calculations utilize the nonequilibrium formula (Theis, 1935; Jacob, 1947), which assumes certain ideal conditions in the aquifer, and which is applicable only if water movement in the aquifer is by laminar flow. It has not been proved that flow in the Snake River basalt is laminar, and it seems likely that turbulence occurs at least in the vicinity of heavily pumped wells. The nonequilibrium method has been used for tentative determinations of hydraulic coefficients because no other method is available at this time. A single aquifer test in the Minidoka area, made by pumping well $8 \mathrm{~S}-24 \mathrm{E}-8 \mathrm{ad} 2$ and using well $8 \mathrm{~S}-24 \mathrm{E}-8 \mathrm{ad} 1$ as an observation well, indicated a coefficient of transmissibility of about $3,000,000 \mathrm{gpd} / \mathrm{ft}$. At other places in the Snake River Plain tests show apparent coefficients of transmissibility ranging from 750,000 to several million $\mathrm{gpd} / \mathrm{ft}$.
The average in Unit B undoubtedly substantially exceeds 1 million gpd/ft, and is very high in comparison to that of ordinary aquifers in other areas.

The coefficient of storage computed from the test of well $8 \mathrm{~S}-24 \mathrm{E}-8 \mathrm{ad} 2$ was 0.04 . Apparent storage coefficients of the basalt at other places in the plain range from 0.01 to 0.05 . Low values apparently are characteristic of the Snake River basalt, in which interconnecting water-bearing openings are large, but on the average are quite sparse, giving the rock a low average porosity.

Locally, the transmissibility of the reservoir rocks ranges between wide extremes, and the difference between the performances of individual wells is correspondingly large. Where the transmissibility is in the low range and the drawdown in a pumped well is greater than is desired, improved performance generally is obtained by deepening the well. On the other hand, many wells produce adequate water with only relatively shallow penetration of the aquifer. Thus, though the locations of areas of lower transmissibility cannot be defined in advance, owing to the heterogeneous character of the basalt, the average regional transmissibility is high and is an adequate basis for estimating the average depth and yield for proposed new wells.

Owing to the high regional transmissibility of the Snake River basalt, local depletion of ground water and lowering of water levels ultimately will affect practically the entire aquifer. Hence, heavy pumping that lowers water levels under Unit B will alter the existing pattern of ground-water underflow and will induce underflow to the unit from a large surrounding area. The total amount of lowering of the water table that would be necessary to induce the required amount of underflow to Unit B cannot be computed from available data. It is assumed from general knowledge and observation, however, that the underflow will be adequate without excessive lowering of water levels. This assumption is not supported by positive evidence, but the plan of development of Unit B, by stage-increments of new wells, will allow adequate opportunity for observation of the effects of increasing pumping. Unfavorable effects could be detected early if, as seems unlikely, the transmission capacity of the reservoir rocks is not adequate for the pumping demand.

\section{Withdrawal Capacity of Wells}

Very simple well construction will be satisfactory at most well sites in Unit B. Most wells will require only a short length of casing through surface sediments to the basalt bedrock. More casing will be needed at a few localities where wells will penetrate unstable materials such as interflow sediments, loose volcanic cinders, or fractured and blocky basalt. The depth of penetration of wells below the water table will depend on local variations in the permeability of the aquifer and the desired volume of water. The characteristics of existing irrigation wells in the Snake River basalt in the Minidoka area are summarized in table 8. The average depth of these wells and the depth to water are greater than the averages expected of wells in Unit B after complete development. For example, only 11 wells in Unit B are included in the group, and many of the numerous private wells are in areas where the depth to water exceeds the average depth in Unit B. 
The average depth to water in wells in Unit B probably will be between 190 and 200 feet, and the average depth of wells probably will be between 290 and 300 feet.

Table 8. - Characteristics of 137 irrigation wells in Unit $\mathrm{B}$ and adjacent area, Minidoka County

[Expressed in feet, except as indicated]

\begin{tabular}{|c|c|c|c|}
\hline Characteristic & Maximum & Minimum & Average \\
\hline Depth........ & 552 & 195 & 339 \\
\hline Diameter (inches)..... & 30 & 12 & 18.5 \\
\hline Length of casing....... & 114 & 4 & 22 \\
\hline Depth to water.......... & 368 & 131 & 238 \\
\hline $\begin{array}{l}\text { Penetration of water- } \\
\text { bearing zone........... }\end{array}$ & 332 & 21 & 101 \\
\hline $\begin{array}{l}\text { Pumping capacity } \\
\text { (cfs)................ }\end{array}$ & 10 & 1 & 5 to 6 \\
\hline Drawdown................ & 25 & $<1$ & $<5$ \\
\hline Horsepower of motor & 450 & 60 & 188 \\
\hline
\end{tabular}

In the vicinity of Unit B the production capacity of wells ranges from moderate to very large, and the . average capacity is large. Thus many individual wells are capable of supplying the full water requirement of one to several farm units. There is no question that wells having very simple design in Unit B will supply the required amount of ground water for irrigation, barring the presence in the aquifer of geologic barriers that prevent the regional body of water from moving at the required rate into the local areas of heavy pumpage.

\section{Effects of Sustained Heavy Pumping}

\section{Local and Regional Water Levels}

Ground-water withdrawals in the North Side Pumping Division and environs have increased in volume each year since 1947, rising from little or none in that year to more than 79,000 acre-feet in 1953. There has not been any appreciable well interference or regional decline of water levels in the Snake River basalt during that time except in well $8 \mathrm{~S}-26 \mathrm{E}-33 \mathrm{bc} 1$. The water level in this well was about half a foot lower in 1953 than in 1952. The effect probably has only local significance. In general there has been a slight net rise of water levels in the Snake River basalt in recent years, ranging from a few inches to almost 3 feet (figs. 4 and 5 , wells $8 \mathrm{~S}-23 \mathrm{E}-2 \mathrm{ba} 1,8 \mathrm{~S}-24 \mathrm{E}-11 \mathrm{ba} 1$, and 9S-20E-1da1).

Local lowering of water levels by sustained heavy pumping in the North Side Pumping Division and adjacent areas probably will cause low-order regional lowering of water levels.

The foreseeable net annual depletion of ground water in the Minidoka area (about 275, 000 acre-feet; see p. 13 is small relative to the total ground-water yield of the Snake River Plain. Unconsumed irrigation water will reach the zone of saturation within a few weeks or months after it is pumped and will offset partly the local effects of pumping. The high rate of transmission of water through the aquifer from surrounding areas also will tend to minimize local lowering of water levels. Large developments elsewhere in the Snake
River Plain also will tend to lower water levels, and the net effect probably will be a small general lowering of water levels throughout the plain, with somewhat greater lowering in or near large pumping projects.

Water levels in alluvium and the Burley lake beds in the Gravity Division in 1953 were less than a foot lower than in 1952, probably because less surface water was applied in 1953. Pumping from the regional groundwater reservoir apparently had little effect on water levels in these aquifers.

\section{Lake Walcott and Snake River}

Below Minidoka Dam the Snake River gains water from irrigation waste and discharge of shallow ground water from the alluvium in both banks of the river. Pumping in Unit B will not draw directly on the shallow ground water, and will not affect the discharge of shallow ground water to the Snake River in the vicinity of the Minidoka North Side Division.

The main water table, at all places where it has been identified in the vicinity of the project, is below the channel of the Snake River. The main water table also is lower than the floor of the western part of Lake Walcott, but the position of the water table directly under the lake is not known. Ground-water pumping in Unit B will not affect the percolation of water out of Lake Walcott or the Snake River where these are above the main water table.

The alluvium, lake beds(?), and some basalt layers on the north side of Lake Walcott are saturated with ground water that percolates from the lake (fig. 8). In well $8 \mathrm{~S}-26 \mathrm{E}-33 \mathrm{bc} 1$ (figs. 7 and 8 ) the perched water is about 70 feet above the regional water table. The perched and main water tables converge and meet 3 to 4 miles north of Lake Walcott. South of Lake Walcott a perched water zone has not been detected. Lowered
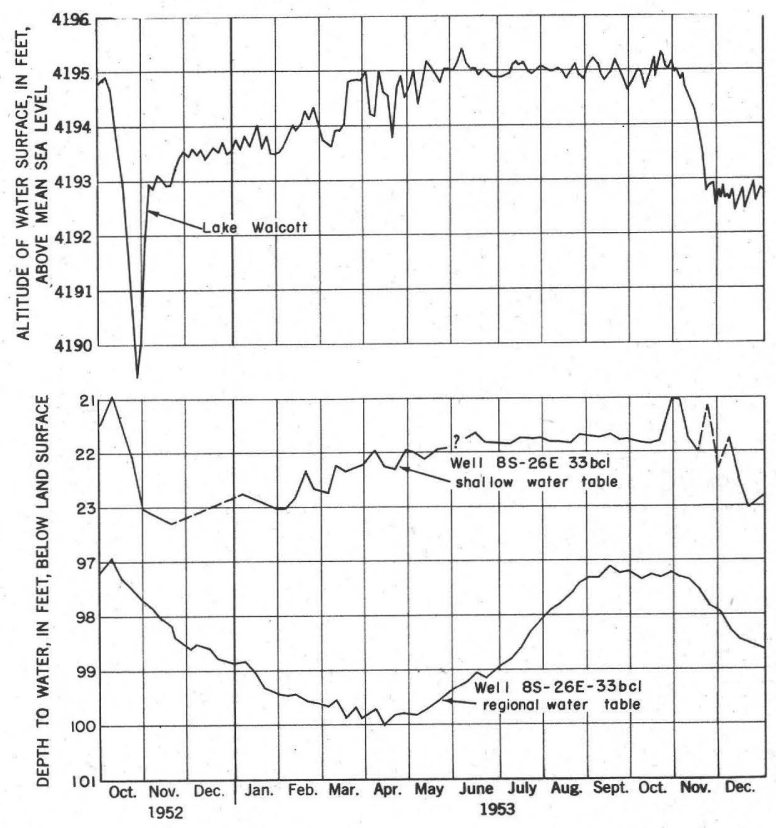

Figure 7.-Water-level fluctuations in well $8 \mathrm{~S}-26 \mathrm{E}-33 \mathrm{bc} 1$ and in Lake Walcott. 
S.W.

A

Well
9S $25 E$

9S $25 E$

DIII Hardpan

Groy lovo

Chocolate lavo

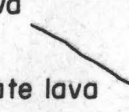

CASSIA COUNTY

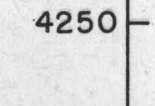

岁 4200

昏

岕

岕 4150

岁

Bosed on drillers' logs of wells

For location of section see plate 1

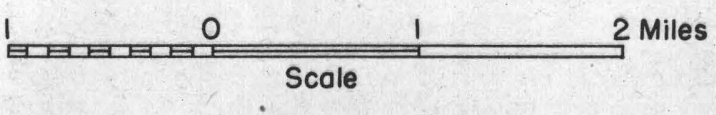

Broken chocolate lavo

Regional water toble

Open black lava

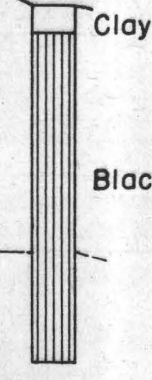

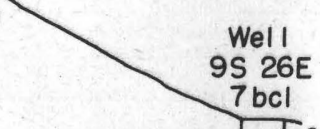

N.E.

\section{$A^{\prime}$}

Well

$8 S 26 E$

$27 a b 1$

Soil and clay

Chocolate lava

$33 \mathrm{bcl}$ Soil

Gray lava

Gray lova

Ash

Red sand

Red sand and some clay

- Local water table

Clay, broken lava, and gravel

Gray lava

Conclomerate

Regional water toble

Hord gray lava

Gravel, clay, and sand

Gray lava

Black lava

Broken black lavo

Block lava

ray lavo

Ash and cinders

Red lavo

Black lava

Clay and rock

Yellow clay

clay and rock

Figure 8. - Relation of Lake Walcott to water levels in nearby wells (generalized). 
regional water levels would not appreciably affect the perched water north of the lake.

\section{Springs in the Snake River Valley Below Milner}

Ground-water inflow to the upstream segment of Lake Walcott may be reduced by a small lowering of the water table, caused by ground-water pumping in the Minidoka area. The reduction probably will be small and the water thus held in underground storage will not appreciably offset depletion by pumping. Thus, the yearly total volume of water discharged by the springs in the Snake River valley eventually will be reduced by about the amount of the net depletion of ground water in the pumped area. The depletion on Unit B will be about 115, 000 acre-feet a year, or about 2.9 percent of the total spring discharge. Total depletion on the project and environs will be about 275,000 acre-feet a year, or about 7 percent of the total. That depletion, however, will be compensated by 30,000 acre-feet of recharge from'surface-water irrigation on Unit A.

It is not possible to segregate the effects on spring discharge of depletion on Unit B from the effects of depletion on adjacent private land. Also, it probably is not possible to segregate the effects of either of these from the effects of other developments to the west and east. It seems likely that ground-water development will continue until depletion of spring discharge becomes important. Thereafter, holders of late priority rights will be first affected by restraints that might be imposed. Water rights for Unit B have relatively early priority.

The above summary is oversimplified because some springs probably will be affected more than others. If only a few springs are seriously depleted, local rights on those springs may be adversely affected at an early stage of development.

\section{Quality of Water}

Results of chemical analyses of 29 samples of ground water and 7 samples from Lake Walcott are summarized in table 9 . Among the factors that determine the chemical suitability of water for irrigation are the ratio of sodium to total cations (percentage of exchangeable sodium), the ratio of bicarbonate to calcium and magnesium, the total amount of dissolved solids, and the amount of boron. The chemical quality of water also affects its utility for domestic and general farm use.

Excessive proportions of sodium cause some types of soil to become impermeable, so that they do not accept water. readily and, once wetted, do not drain satisfactorily. The Wilcox method of expressing the sodium hazard (Wilcox, 1948) is to plot the percentage of exchangeable sodium against specific conductance (in micromhos per centimeter, fig. 9). This method does not express an exact ratio of sodium adsorption by the soil. Another method (Richards, 1954) is based on the sodium-adsorption ratio (SAR), expressed by the equation in which $\mathrm{Na}^{+}, \mathrm{Ca}^{++}$, and $\mathrm{Mg}^{++}$represent respective concentrations, in milliequivalents per liter, of sodium, calcium, and magnesium. The sodium-adsorption ratios of 24 samples of water from the Snake River basalt in the Minidoka area range from 0.57 to 2.2 .1 / Therefore, the sodium hazard is low. 2 /

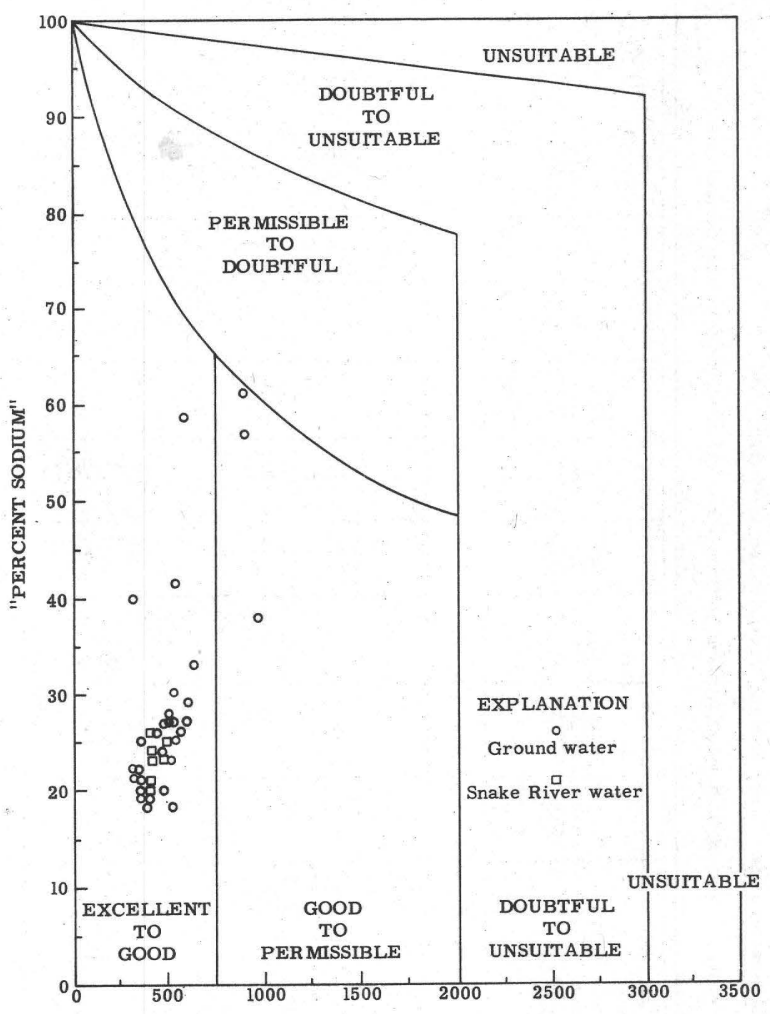

SPECIFIC CONDUCTANCE IN MICROMHOS PER CM AT $25^{\circ} \mathrm{C}$

\section{Figure 9.-Classification of irrigation water from} the Minidoka area.

Specific conductance of water, a measure of electrical conductivity, is related directly to the ionized solids in the water and hence affords an approximate measure of the amount of dissolved solids. The specific conductance of water also indicates the suitability of the water for irrigation. In general, water having conductivity values less than 750 micromhos is satisfactory for irrigation so far as dissolved solids are concerned. The specific conductance of ground-water samples from the Snake River basalt ranges from 311 to 984 micromhos. Water from well 9S-22E-33ad1, which has by far the highest specific conductance and the highest dissolved mineral content, may not be suitable for use on tight, poorly drained soils.

1/ The ratio for water from some wells listed in table 9 ranges up to 4.4. All wells having ratios higher than 2.2 tap water in Burley lake beds.

2/ Sodium and potassium are reported together in some analyses in table 9 and the combined amount necessarily is treated as sodium to compute the SAR, percentage of exchangeable sodium, and residual sodium carbonate. 


\begin{tabular}{|c|c|c|c|c|c|c|c|c|c|c|c|c|c|c|c|c|c|c|c|c|c|c|c|c|}
\hline \multirow[b]{2}{*}{$\begin{array}{l}\text { Well or } \\
\text { sample } \\
\text { no. }\end{array}$} & \multirow{2}{*}{$\begin{array}{c}\text { Date } \\
\text { of } \\
\text { collection }\end{array}$} & \multirow{2}{*}{$\begin{array}{l}\text { Tem- } \\
\text { pera- } \\
\text { ture } \\
\left({ }^{\circ} \mathrm{F}\right)\end{array}$} & \multirow[b]{2}{*}{$\mathrm{pH}$} & \multirow{2}{*}{$\begin{array}{l}\text { Specific } \\
\text { conduct- } \\
\text { ance } \\
\text { (micro- } \\
\text { mhos at } \\
25^{\circ} \mathrm{C} \text { ) }\end{array}$} & \multirow{2}{*}{$\begin{array}{l}\text { Silica } \\
\left(\mathrm{SiO}_{2}\right)\end{array}$} & \multirow{2}{*}{$\begin{array}{l}\text { Iron } \\
(\mathrm{Fe})\end{array}$} & \multirow{2}{*}{\begin{tabular}{|c|} 
Man- \\
gan- \\
ese \\
(Mn)
\end{tabular}} & \multirow{2}{*}{$\begin{array}{l}\text { Cal- } \\
\text { cium } \\
\text { (Ca) }\end{array}$} & \multirow{2}{*}{$\begin{array}{l}\text { Mag- } \\
\text { ne- } \\
\text { sium } \\
(\mathrm{Mg})\end{array}$} & \multirow{2}{*}{$\begin{array}{l}\text { Sodium } \\
(\mathrm{Na})\end{array}$} & \multirow[b]{2}{*}{$\begin{array}{l}\text { Potas- } \\
\text { sium } \\
\text { (K) }\end{array}$} & \multirow{2}{*}{$\begin{array}{l}\text { Bicar- } \\
\text { bonate } \\
\left(\mathrm{HCO}_{3}\right)\end{array}$} & \multirow{2}{*}{$\begin{array}{c}\text { Car- } \\
\text { bonate } \\
\text { (COs) }\end{array}$} & \multirow[b]{2}{*}{$\begin{array}{c}\text { Sul- } \\
\text { fate } \\
\left.\text { (SO }_{4}\right)\end{array}$} & \multirow[b]{2}{*}{$\begin{array}{l}\text { Chlo- } \\
\text { ride } \\
\text { (Cl) }\end{array}$} & \multirow[b]{2}{*}{$\begin{array}{l}\text { Fluo- } \\
\text { ride } \\
\text { (F) }\end{array}$} & \multirow[b]{2}{*}{$\mid \begin{array}{c}\mathrm{Ni}- \\
\text { trate } \\
\left(\mathrm{NO}_{3}\right)\end{array}$} & \multirow[b]{2}{*}{$\begin{array}{l}\text { Bo- } \\
\text { ron } \\
\text { (B) }\end{array}$} & \multirow[b]{2}{*}{\begin{tabular}{|c|} 
Dis- \\
solved \\
solids
\end{tabular}} & $\begin{array}{l}\text { Hard } \\
\text { as } \mathrm{Ca}_{2}\end{array}$ & $\begin{array}{l}\text { dness } \\
\mathrm{aCO}_{3}\end{array}$ & & Sodium- & Residual \\
\hline & & & & & & & & & & & & & & & & & & & & Total & $\begin{array}{c}\text { Non- } \\
\text { car- } \\
\text { bon- } \\
\text { ate }\end{array}$ & $\begin{array}{l}\text { sodium } \\
\text { soding }\end{array}$ & $\begin{array}{l}\text { tion } \\
\text { ratio }\end{array}$ & $\begin{array}{c}\text { car- } \\
\text { bonate }\end{array}$ \\
\hline & & & & & & & & & & Ground wat & ater: Minic & doka Cou & & & & & & & & & & & & \\
\hline 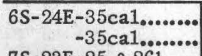 & $\begin{array}{l}6-23-53 \\
9-28-53\end{array}$ & \begin{tabular}{|c|}
58 \\
$\ldots . . . . . . . . .$. \\
\end{tabular} & $\begin{array}{l}8.2 \\
7.6 \\
\end{array}$ & $\begin{array}{l}337 \\
338 \\
30\end{array}$ & $\begin{array}{l}31 \\
37\end{array}$ & $\begin{array}{l}0.01 \\
0\end{array}$ & $\begin{array}{r}0 \\
0 . . . . . . . . . .\end{array}$ & $\begin{array}{l}33 \\
30 \\
30\end{array}$ & $\begin{array}{l}13 \\
13\end{array}$ & $\begin{array}{l}17 \\
17 \\
02\end{array}$ & $\begin{array}{l}3.2 \\
3.5\end{array}$ & $\begin{array}{l}152 \\
150\end{array}$ & 0 & $\begin{array}{l}29 \\
28\end{array}$ & $\begin{array}{l}13 \\
12 \\
2\end{array}$ & $\begin{array}{r}0.7 \\
.8\end{array}$ & $\begin{array}{l}1.5 \\
1.4\end{array}$ & $\begin{array}{l}0.06 \\
\ldots \ldots \ldots\end{array}$ & $\begin{array}{l}215 \\
199\end{array}$ & $\begin{array}{l}136 \\
128\end{array}$ & $\begin{array}{r}11 \\
5\end{array}$ & \begin{tabular}{l|}
21 \\
22 \\
\end{tabular} & $\begin{array}{r}0.63 \\
.65\end{array}$ & $\begin{array}{l}0 \\
0\end{array}$ \\
\hline 7S-23E-25 \& 261..... & $\begin{array}{r}1949 \\
6-29-51\end{array}$ & -............ & $\ldots \ldots$ & $\begin{array}{l}430 \\
353\end{array}$ & $\ldots$ & ............. & 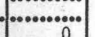 & $\begin{array}{l}39 \\
36\end{array}$ & $\begin{array}{l}13 \\
14\end{array}$ & $\begin{array}{r}23 \\
17\end{array}$ & 7.4 & $\begin{array}{l}138 \\
161\end{array}$ & 10 & $\begin{array}{l}49 \\
32\end{array}$ & 26 & $\ldots . .$. & $\ldots$ & $\ldots \ldots$ & & & ........ & 24 & .82 & 0 \\
\hline $8 \mathrm{~S}-23 \mathrm{E}-2 \mathrm{bd} 1 \ldots$ & $\begin{array}{l}0-29-01 \\
9-17-50\end{array}$ & $\ldots$ & 7.6 & $\begin{array}{l}353 \\
609\end{array}$ & $\begin{array}{l}34 \\
43\end{array}$ & .01 & & $\begin{array}{l}36 \\
58\end{array}$ & $\begin{array}{l}14 \\
22\end{array}$ & 40 & & $\begin{array}{l}161 \\
249\end{array}$ & 0 & $\begin{array}{l}32 \\
50\end{array}$ & $\begin{array}{l}13 \\
44\end{array}$ & .7 & $\begin{array}{l}1 \\
6.4\end{array}$ & $\mid \begin{array}{l}.15 \\
.02\end{array}$ & $\begin{array}{l}224 \\
386\end{array}$ & $\begin{array}{l}147 \\
235\end{array}$ & $\begin{array}{l}15 \\
31\end{array}$ & $\begin{array}{l}20 \\
27\end{array}$ & $\begin{array}{r}.61 \\
1.1\end{array}$ & $\begin{array}{l}0 \\
0\end{array}$ \\
\hline$-27 \mathrm{bd1} . . . . . . . . .$. & $6-29-51$ & 55 & 7.8 & 614 & 36 & .03 & 0 & 57 & 22 & 37 & 7.6 & 249 & 0 & 46 & 42 & $\because .3$ & 5.5 & .15 & $\begin{array}{l}\infty 00 \\
377\end{array}$ & $\begin{array}{l}230 \\
232\end{array}$ & $\begin{array}{l}31 \\
28\end{array}$ & 25 & 1.2 & 0 \\
\hline $\begin{array}{r}8 \mathrm{~S}-24 \mathrm{E}-7 \mathrm{da} 1 \ldots . . . . . . \\
-\end{array}$ & $\begin{array}{l}6-11-49 \\
9-17-50\end{array}$ & $\begin{array}{l}55 \\
56.5\end{array}$ & $\cdots \cdots$ & $\begin{array}{l}502 \\
519\end{array}$ & $\begin{array}{l}40 \\
39\end{array}$ & .02 & & $\begin{array}{l}46 \\
46\end{array}$ & $\begin{array}{l}16 \\
18\end{array}$ & $\begin{array}{l}36 \\
34\end{array}$ & 6.1 & $\begin{array}{l}202 \\
206\end{array}$ & 0 & $\begin{array}{l}43 \\
46\end{array}$ & $\begin{array}{l}34 \\
38\end{array}$ & .4 .4 & 1.9 & $\left|\begin{array}{l}0 \\
02\end{array}\right|$ & $\begin{array}{l}316 \\
327\end{array}$ & $\begin{array}{l}181 \\
189\end{array}$ & 16 & $\begin{array}{r}30 \\
27\end{array}$ & 1.2 & 0 \\
\hline -11ba1.......... & $9-17-50$ & $56^{\circ}$ & & 477 & 41 & & & 43 & 17 & 31 & & 188 & 0 & 44 & 31 & 0 & $\begin{array}{r}1.0 \\
.9\end{array}$ & ......... & $\begin{array}{l}327 \\
300\end{array}$ & $\begin{array}{l}189 \\
177\end{array}$ & $\begin{array}{l}20 \\
23\end{array}$ & $\begin{array}{l}27 \\
27\end{array}$ & $\begin{array}{l}1.2 \\
1.0\end{array}$ & $\begin{array}{l}0 \\
0\end{array}$ \\
\hline$-11 \mathrm{bal}, \ldots . . . .$. & 6-29-51 & $\begin{array}{l}54 \\
57\end{array}$ & 7.8 & $\begin{array}{l}457 \\
654\end{array}$ & 37 & .02 & 0 & $\begin{array}{l}43 \\
53\end{array}$ & 17 & 26 & 4 & $\begin{array}{l}186 \\
223\end{array}$ & $\begin{array}{l}0 \\
8\end{array}$ & 44 & $\begin{array}{l}26 \\
54\end{array}$ & .5 & 1.2 & .11 & 285 & 177 & 25 & 24 & .85 & 0 \\
\hline $8 \mathrm{~S}-25 \mathrm{E}-16 \mathrm{bb} 1 \ldots \ldots \ldots$ & $\begin{array}{l}9-19-50 \\
6-3-53\end{array}$ & $\begin{array}{l}57 \\
53\end{array}$ & $\mid-\ldots .70$ & $\begin{array}{l}654 \\
381\end{array}$ & $\begin{array}{l}42 \\
30\end{array}$ & .05 & $\cdots$ & $\begin{array}{l}53 \\
40\end{array}$ & $\begin{array}{l}22 \\
15\end{array}$ & $\begin{array}{l}51 \\
17\end{array}$ & 2.9 & $\begin{array}{l}223 \\
162\end{array}$ & $\begin{array}{l}8 \\
0\end{array}$ & $\begin{array}{l}57 \\
37\end{array}$ & & .6 & $\begin{array}{l}3.1 \\
1.0\end{array}$ & ........ & $\begin{array}{l}400 \\
244\end{array}$ & $\begin{array}{l}222 \\
162\end{array}$ & 26 & $\begin{array}{c}33 \\
18\end{array}$ & 1.5 & 0 \\
\hline $8 S-20 E-1 \mathrm{cbl} 1,3 . . . .$. & $\begin{array}{l}0-3-33 \\
4-8-49\end{array}$ & & & $\begin{array}{l}381 \\
388\end{array}$ & $\begin{array}{l}30 \\
32\end{array}$ & & & $\begin{array}{l}40 \\
40\end{array}$ & $\begin{array}{l}10 \\
15\end{array}$ & 17 & ........ & 160 & & $\begin{array}{l}31 \\
39\end{array}$ & 18 & & 1.5 & .01 & 241 & $\begin{array}{l}162 \\
162\end{array}$ & $\begin{array}{l}29 \\
30\end{array}$ & $\begin{array}{l}18 \\
19\end{array}$ & .58 & 0 \\
\hline$-16 \mathrm{da1} 1 . . . . . . . . .$. & $9-17-50$ & 56 & $\ldots \ldots$ & 489 & 46 & $\ldots$ & (n...... & 46 & 18 & 32 & (.......... & 210 & 0 & 43 & 29 & (1)...... & 1.2 & .02 & 319 & 189 & 17 & 27 & 1.00 & 0 \\
\hline 9S-22E-33ad1......... & $6-29-51$ & ......... & 7.90 & 984 & 32 & .01 & & 81 & 30 & 92 & 5.2 & 373 & 0 & 105 & 74 & 0 & 9.4 & .25 & 600 & 326 & 20 & 38 & 2.2 & 0 \\
\hline $9 \mathrm{~S}-24 \mathrm{E}-1 \mathrm{db} 22^{2}$ & $6-10-49$ & 59 & ......... & 493 & 26 & $\ldots$ & & 52 & 16 & 20 & & 212. & & 25 & 25 & .4 & 3.2 & .01 & 272 & 196 & 22 & 27 & .62 & 0 \\
\hline$-1 \mathrm{db} 22 \ldots \ldots$ & $10-27-49$ & 59 & $\ldots \ldots$ & 576 & 30 & $\ldots \ldots$ & {$[\ldots . . . . . .$.} & 62 & 18 & 36 & $\ldots \ldots \ldots$ & 240 & 0 & 48 & 35 & .4 & 13 & ......... & $\ldots$ & 228 & 32 & 26 & 1.0 & 0 \\
\hline $\begin{array}{l}-29 \mathrm{ab} 3{ }^{2} \ldots \ldots \ldots . . \\
-29 \mathrm{ab} 3{ }^{2} \ldots \ldots . . .\end{array}$ & $\begin{array}{l}6-3-53 \\
9-29-53\end{array}$ & $\begin{array}{l}71 \\
66\end{array}$ & \begin{tabular}{|l|}
7.6 \\
7.6
\end{tabular} & $\begin{array}{l}901 \\
894\end{array}$ & $\begin{array}{l}47 \\
50\end{array}$ & $0^{.11}$ & $\mid \begin{array}{r}0 \\
\ldots . . . . . . . . .\end{array}$ & $\begin{array}{l}40 \\
35\end{array}$ & $\begin{array}{l}15 \\
14\end{array}$ & $\begin{array}{l}114 \\
122\end{array}$ & $\begin{array}{l}19 \\
20\end{array}$ & $\begin{array}{l}194 \\
195\end{array}$ & $\begin{array}{c}0 \\
\ldots . . .\end{array}$ & $\begin{array}{l}21 \\
21\end{array}$ & $\begin{array}{l}172 \\
172\end{array}$ & .8 & $\begin{array}{l}1.1 \\
1.6\end{array}$ & $\begin{array}{l}.18 \\
.08\end{array}$ & $\begin{array}{l}572 \\
527\end{array}$ & $\begin{array}{l}162 \\
145\end{array}$ & $\begin{array}{l}2 \\
0\end{array}$ & $\begin{array}{l}57 \\
61\end{array}$ & $\begin{array}{l}3.9 \\
4.4\end{array}$ & ${ }^{0} .30$ \\
\hline & & & & & & & & & & Ground wa & rater: Linc & coln Cour & & & & & & & & & & & & \\
\hline $\begin{array}{r}7 \mathrm{~S}-23 \mathrm{E}-5 \mathrm{ccc} 1 \ldots . . . . . . . \\
-5 \mathrm{ccc} 1 \ldots . . . . \\
\end{array}$ & $\begin{array}{r}6-3-53 \\
10-2-53 \\
\end{array}$ & $\begin{array}{r}50 \\
5 . . . . . . . . \\
\end{array}$ & \begin{tabular}{|l|}
7.8 \\
8.3 \\
\end{tabular} & $\begin{array}{l}449 \\
351 \\
\end{array}$ & $\begin{array}{l}31 \\
36 \\
\end{array}$ & $\begin{array}{r}0.07 \\
.00 \\
\end{array}$ & $\begin{array}{r}0 \\
\ldots \ldots \ldots . . . . . .\end{array}$ & $\begin{array}{l}32 \\
30 \\
\end{array}$ & $\begin{array}{l}15 \\
13 \\
\end{array}$ & $\begin{array}{l}18 \\
20 \\
\end{array}$ & $\begin{array}{l}3.3 \\
3.8 \\
\end{array}$ & $\begin{array}{l}150 \\
149 \\
\end{array}$ & $\begin{array}{r}0 \\
0 . . . . . . . . . \\
\end{array}$ & $\begin{array}{l}30 \\
30 \\
\end{array}$ & $\begin{array}{l}17 \\
17 \\
\end{array}$ & $\begin{array}{r}0.5 \\
.6 \\
\end{array}$ & $\begin{array}{l}1.2 \\
1.9 \\
\end{array}$ & $\begin{array}{r}0.08 \\
.10 \\
\end{array}$ & $\begin{array}{l}220 \\
221 \\
\end{array}$ & \begin{tabular}{l|}
142 \\
128 \\
\end{tabular} & $\begin{array}{r}19 \\
6 \\
\end{array}$ & $\begin{array}{l}21 \\
25 \\
\end{array}$ & $\begin{array}{r}0.66 \\
.77 \\
\end{array}$ & $\begin{array}{l}0 \\
0\end{array}$ \\
\hline & & & & & & & & & & Ground $w$ & water: Bla & aine Coun & & & & & & & & & & & & \\
\hline $\begin{array}{r}7 \mathrm{~S}-26 \mathrm{E}-1 \mathrm{cc} 1 . . .0 . . . .0 \\
-1 \mathrm{cc} 1 . . . . . . .\end{array}$ & $\begin{array}{l}6-3-53 \\
9-29-53\end{array}$ & $\begin{array}{c}54 \\
\ldots \ldots \ldots\end{array}$ & \begin{tabular}{|l|}
7.7 \\
8.6
\end{tabular} & $\begin{array}{l}313 \\
311\end{array}$ & $\begin{array}{l}30 \\
34\end{array}$ & $\begin{array}{l}0.10 \\
0\end{array}$ & $\mid \begin{array}{c}0 \\
\ldots \ldots \ldots . .0 .0\end{array}$ & $\begin{array}{l}32 \\
32\end{array}$ & $\begin{array}{l}11 \\
9.4\end{array}$ & $\begin{array}{l}15 \\
19\end{array}$ & $\begin{array}{l}3.2 \\
3.5\end{array}$ & $\begin{array}{l}146 \\
139\end{array}$ & $\begin{array}{l}0 \\
5\end{array}$ & $\begin{array}{l}22 \\
22\end{array}$ & $\begin{array}{l}13 \\
12\end{array}$ & $\begin{array}{r}0.7 \\
.8\end{array}$ & $\begin{array}{l}1.4 \\
2.4\end{array}$ & $\begin{array}{r}0.08 \\
.04\end{array}$ & $\begin{array}{l}200 \\
202\end{array}$ & $\begin{array}{l}125 \\
118\end{array}$ & $\begin{array}{l}5 \\
0\end{array}$ & $\begin{array}{l}20 \\
25\end{array}$ & $\begin{array}{l}0.58 \\
.76\end{array}$ & $\begin{array}{l}0 \\
0\end{array}$ \\
\hline 8S-26E-15bd1.......... & $\begin{array}{r}6-10-49 \\
10-28-49\end{array}$ & $\begin{array}{l}57 \\
57\end{array}$ & $\ldots \ldots$ & $\begin{array}{l}594 \\
545\end{array}$ & $\begin{array}{l}39 \\
39\end{array}$ & $\ldots \ldots . . .$. & $0 . . . . . . . . . . .0$ & $\begin{array}{l}35 \\
40\end{array}$ & $\begin{array}{l}16 \\
16\end{array}$ & $\begin{array}{l}60 \\
53\end{array}$ & -.............. & $\begin{array}{l}193 \\
166\end{array}$ & & $\begin{array}{l}45 \\
44\end{array}$ & $\begin{array}{l}54 \\
51\end{array}$ & $\begin{array}{l}.4 \\
.8\end{array}$ & $\begin{array}{l}1 \\
1.6\end{array}$ & .02 & 346 & $\begin{array}{l}154 \\
166\end{array}$ & $\begin{array}{l}0 \\
7\end{array}$ & $\begin{array}{l}59 \\
41\end{array}$ & $\begin{array}{l}2.11 \\
1.8\end{array}$ & $0^{.10}$ \\
\hline $8 \mathrm{~S}-27 \mathrm{E}-16 \mathrm{cd1} 1 . . . . . .$. & $6-3-53$ & 51 & 7.3 & 468 & 29 & .09 & & 50 & 16 & 22 & 3.2 & 178 & & 49 & 28 & .4 & 3 & .10 & 298 & 191 & 45 & 20 & .69 & 0 \\
\hline$-16 \mathrm{cd1} . . . . . . . . .$. & $10-2-53$ & ....... & 7.8 & 465 & 35 & $0^{\circ 0}$ & & 47 & 15 & 25 & 3.8 & 182 & & 48 & 27 & .6 & 4.2 & .02 & 297 & 179 & 30 & 23 & .81 & 0 \\
\hline $8 \mathrm{~S}-28 \mathrm{E}-16 \mathrm{da1} . . . . . . .$. & $6-4-53$ & 50 & 7.7 & $\begin{array}{l}523 \\
515\end{array}$ & 26 & .04 & & 59 & 20 & $\begin{array}{r}23 \\
29\end{array}$ & 3.6 & 198 & & $\begin{array}{l}59 \\
58\end{array}$ & 33 & .4 & 2.3 & .10 & 34 & 229 & 67 & 18 & .66 & 0 \\
\hline$-16 \mathrm{da} 1 \ldots . . . . . .$. & $9-29-53$ & ........ & 7.6 & 515 & 32 & .09 & ............ & 56 & 16 & 29 & 3.8 & 202 & & 58 & 32 & .6 & 2.4 & .08 & 329 & 206 & 40 & 23 & .88 & 0 \\
\hline & & & & & & & & & Surfac & water: $\mathrm{S}_{\mathrm{r}}$ & Snake Rive & er at Mir & idoka Dan & & & & & & & & & & & \\
\hline$\left({ }^{(3}\right) \ldots, \ldots \ldots \ldots \ldots \ldots \ldots$ & 1948-49 & 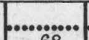 & $\ldots$ & 410 & 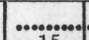 & $\ldots$ & 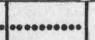 & 43 & 16 & 19 & 10.1 & 158 & 10 & 44 & 26 & & & $\infty$ & 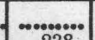 & & & 19 & 0.64 & 0 \\
\hline 1 & $6-10-49$ & 68 & $\ldots \ldots$ & 409 & 15 & 年 & {$[\ldots . . . . . . . .$.} & 44 & 13 & 22 & $\ldots . . . . . .$. & 166 & & 39 & 16 & 0.4 & 0 & 10 & 238 & 163 & 16 & 23 & .75 & 0 \\
\hline $2, \ldots \ldots \ldots \ldots \ldots \ldots \ldots \ldots$ & $10-27-49$ & 45 & $\ldots \ldots$ & 475 & 24 & $\ldots . . . .$. & . ............. & 50 & 16 & 29 & …........... & $\begin{array}{l}203 \\
1180\end{array}$ & 0 & 48 & 24 & .8 & 1.8 & $\ldots . .$. & ............. & 191 & 24 & 25 & .91 & 0 \\
\hline 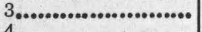 & $9-16-50$ & 62.5 & 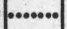 & 403 & 15 & ........ & |............ & 44 & 15 & 21 & ............... & 188 & 0 & 36 & 18 & & .2 & & $\ldots$ & 172 & 17 & 21 & .70 & 0 \\
\hline $4 \ldots \ldots \ldots \ldots \ldots \ldots \ldots$ & $\begin{array}{r}6-10-49 \\
10-27-49\end{array}$ & $\begin{array}{l}68 \\
45\end{array}$ & $\ldots \ldots$ & $\begin{array}{l}409 \\
472\end{array}$ & $\begin{array}{l}15 \\
25\end{array}$ & .......... & .............. & $\begin{array}{l}46 \\
49\end{array}$ & 14 & $\begin{array}{r}19 \\
26\end{array}$ & 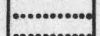 & $\begin{array}{l}180 \\
197\end{array}$ & & $\begin{array}{l}39 \\
48\end{array}$ & ${ }_{24}^{17}$ & .4 & ${ }_{14}^{1}$ & .01 & 240 & $\begin{array}{l}172 \\
192\end{array}$ & $\begin{array}{l}25 \\
31\end{array}$ & 24 & .63 & 0 \\
\hline 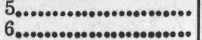 & $\mid \begin{array}{r}10-27-49 \\
9-16-50\end{array}$ & $\begin{array}{l}45 \\
62.5\end{array}$ & $\mid \ldots \ldots \ldots$ & $\begin{array}{l}472 \\
403\end{array}$ & $\begin{array}{l}25 \\
14\end{array}$ & $\ldots \ldots \ldots$ & $\mid$ & $\begin{array}{l}49 \\
44\end{array}$ & $\begin{array}{l}17 \\
15\end{array}$ & $\begin{array}{l}26 \\
20\end{array}$ & a............... & $\begin{array}{l}197 \\
183\end{array}$ & $\begin{array}{l}0 \\
0\end{array}$ & $\begin{array}{l}48 \\
37\end{array}$ & $\begin{array}{l}24 \\
18\end{array}$ & & $\begin{array}{r}1.4 \\
.2\end{array}$ & ........... & 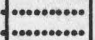 & $\begin{array}{l}192 \\
172\end{array}$ & $\begin{array}{l}31 \\
22\end{array}$ & $\begin{array}{l}23 \\
20\end{array}$ & $\begin{array}{l}.82 \\
.66\end{array}$ & $\begin{array}{l}0 \\
0\end{array}$ \\
\hline
\end{tabular}


Calcium and magnesium tend to precipitate from irrigation water that is high in bicarbonate, thereby increasing the relative proportion of sodium in the soil water. The residual sodium carbonate is computed as follows: $\left(\mathrm{CO}_{3}^{--}+\mathrm{HCO}_{3}^{-}\right)-\left(\mathrm{Ca}^{++}+\mathrm{Mg}^{++}\right)$, all ions being expressed in milliequivalents per liter. Water containing less than 1.25 milliequivalents per liter of residual sodium carbonate probably is safe; water containing 1.25 to 2.5 milliequivalents per liter is marginal; water having more than 2.5 milliequivalents per liter is unsafe. The range of residual sodium carbonate is from 0 to 0.1 in samples of water from the Snake River basalt and up to 0.3 in water from the Burley lake beds. "Water from the basalt, therefore, is safe for irrigation according to that criterion.

A small amount of boron is essential to plant growth, but amounts in excess of the optimum are toxic to many cultivated plants. Boron in amounts less than $0.3 \mathrm{ppm}$ generally is beneficial to plants. The maximum concentration of boron in ground-water samples from the Snake River basalt is $0.25 \mathrm{ppm}$.

Calcium and magnesium cause hardness in water. Moderate hardness is desirable in irrigation water because the minerals are necessary for plant growth, but excessive hardness is harmful. Excessive hardness also is objectionable in water for domestic and industrial uses. The ground water in the Minidoka area is hard, but the amounts of calcium and magnesium in the water do not affect adversely its suitability for irrigation.

Potassium is necessary for soil fertility, and silica may be important to plant growth and to the development of good soil texture. Fluoride in excess of about $1.5 \mathrm{ppm}$ causes mottling of teeth in children but in smaller amounts it inhibits tooth decay. Excessive iron stains plumbing fixtures and clogs pipes. The amounts of these constituents and those of sulfate, chloride, and nitrate are not excessive in the ground water and surface water in the Minidoka area.

In summary, ground water in the Snake River basalt is suitable for irrigation according to the ordinary criteria for classifying irrigation water. The water is hard but is otherwise generally satisfactory for domestic use. Treatment would be necessary to make the water suitable for many industrial purposes.

\section{CONCLUSIONS AND SUGGESTIONS}

The Snake River basalt is the most extensive aquifer in Idaho and the Snake River Plain forms the largest unified ground-water reservoir in the Pacific Northwest. The capacity of the reservoir to yield large quantities of water to wells, with only small drawdown and small regional lowering of water levels has been demonstrated in the Minidoka area and in other parts of the plain. The depth to water beneath Unit B ranges from 120 to more than 300 feet and averages about 200 feet. The proposed heavy pumping in and near Unit B probably will lower the water table only a few feet. Decline of the water table during heavy pumping will induce large inflow of ground water through the basalt from adjacent areas. The decline of water levels thus will be no greater than that required to produce the needed volume of inflow. Equilibrium probably will be reached during each pumping season at some undeter- mined level lower than present water levels in Unit B. Although the amount of lowering cannot be predicted accurately, it seems unlikely that it will exceed 10 feet. For project-planning purposes, therefore, it is reasonable to assume that future pumping lifts will not be more than 10 feet greater than present lifts.

Perched shallow ground water in the North Side Gravity Division is discharged partly by seepage into the Snake River and partly by underground "spill" off the northern and western edges of the Burley lake beds, on which the shallow water is perched. Pumping in Unit B of the Pumping Division will not affect either the amount of water in perched storage or the rate of natural discharge of this water into the Snake River. The rate and amount of underflow of the perched water to the regional water table also will be unaffected.

The hydrologic relations between Lake Walcott and the main and perched water tables around the lake are not fully disclosed by available evidence. Data from test holes, production wells, and observation wells in the vicinity of the lake, however, do not suggest a direct hydraulic relation between the lake and the main water table in areas that will be affected directly by pumping in Unit B. Therefore, pumping in Unit B probably will not increase percolation loss from the lake.

The Geological Survey currently is studying records of spring discharge and other hydrologic phenomena in the Snake River valley below Milner. The study is not complete, but so far spring discharge has not been found to be appreciably affected by new ground-water developments on the Snake River Plain. Discharge records for representative springs meet the usual standards of accuracy for gage records, with errors of no more than 3 to 5 percent. Future depletion of spring discharge, caused by present and foreseeable future pumping in Unit B and in private projects elsewhere, probably will amount to about 10 to 15 percent of the yearly total discharge from all springs (see p. 14). Thus, depletion probably will be detected readily if springs that are continuously gaged are affected. Accurate records are not available of the total discharge from all springs. The total discharge can be estimated only approximately from incomplete inflow-outfiow records of the reach of the Snake River between Milner and King Hill. Hence, available records do not permit accurate computation of small-percentage changes in the total discharge from all the springs.

Owing to the long distance-more than 20 milesfrom the western edge of Unit B to the nearest large spring (Devil's Washbowl), effects on spring discharge will be spread over a period much longer than the pumping season. As development on Unit B and in other areas progresses, its effect on the springs will increase gradually. The seasonal fluctuation in rates of discharge may increase and the times of minimum and maximum flow may shift.

An intensive hydrologic study should be made of the Snake River valley from Milner to King Hill, and the study should make special reference to spring discharge: accurate, continuing discharge records should be obtained, and a number of gaging stations should be added to those now operating. Such records might well forestall some controversies and help to resolve others. 
Operation of observation wells in the project area and environs should be continued, and the number of observation stations adjacent to and west of the project should be increased. The seasonal cycle of fluctuations of ground-water levels may change: the range of cyclic fluctuations probably will increase, and the times of high and low levels may shift. Such changes should be matters of record.

The position and configuration of the water table in Unit $\mathrm{B}$ and adjacent areas to the north are reasonably well defined by existing data. Elsewhere on the plain they are poorly defined. Accurate water-table mapping should be extended and the map for the project area and environs should be refined and revised periodically to show seasonal and long-term trends in the changing form of the water table. The map would have permanent value as a record of the effects of development and would be useful also as an aid in choosing sites and specifying construction characteristics for new groups of wells.

\section{SELECTED BIBLIOGRAPHY}

Jacob, C. E., 1947, Drawdown test to determine effective radius of artesian well: Am. Soc. Civ. Eng. Trans., v. 112, p. 1047-1070.

Nace, R. L., 1948, Preliminary report on ground water in Minidoka County, Idaho, with special reference to the North Side Pumping Division of the Minidoka Project: U. S. 81 st Cong., 2d sess., H. Doc. 721 , p. 157-207.

Newell, R. J., 1949, Minidoka Project, North Side Pumping Division, Idaho: U. S. Bur. Reclamation, Project Planning Rept. no. 1-5.53.1-1, 159 p.
Richards, L. A., 1954, Diagnosis and improvement of saline and alkali soils: U. S. Dept. Agriculture Handbook no. 60,160 p.

Russell, I. C., 1902, Geology and water resources of the Snake River Plains of Idaho: U. S. Geol. Survey Bull. 199, 192 p.

Stearns, H. T., Crandall, Lynn, and Steward, W. G., 1938, Geology and ground-water resources of the Snake River Plain in southeastern Idaho: U. S. Geol. Survey Water-Supply Paper 774.

Theis, C. V., 1935, The relation between the lowering of the piezometric surface and the rate and duration of discharge of a well using ground-water storage: Am. Geophys. Union Trans., pt. 2,"p. 519-524.

Wilcox, L. V., 1948, Explanation and interpretation of analysis of irrigation waters: U. S. Dept. Agriculture Circ. 784.

\section{UNPUBLISHED REPORTS}

Crandall, Lynn, 1953, Ground-water flows of the Snake River Plain: Presented at Idaho State Recl. Assoc. Ann. Convention, Pocatello, Idaho, in March.

Fader, S. W., and Mower, R. W., 1952, Records of wells and ground-water levels in Minidoka County, Idaho: In files of U. S. Geol. Survey.

Idaho State Department Reclamation, 1950-53, Water distribution and hydrometric work, Water District 36, Snake River, Idaho: Ann. repts., 1950-53.

Mower, R. W., 1953, Records of wells and groundwater levels in eastern Jerome County, Idaho: In files of U. S. Geol. Survey. 